\title{
A Sustainable, Integrated Multi-level Floating Farm concept: Singapore perspective.
}

\author{
Rasim Asgarov $^{\mathrm{a}}$, David MacLaren ${ }^{\mathrm{b}}$, Mohammed Abdul Hannan*c, Prateek Khandelwal ${ }^{\mathrm{d}}$ \\ ${ }^{a}$ CEng, FRINA, FIMarEST, independent researcher; ${ }^{b}$ PEng, independent researcher; ${ }^{c}$ Faculty of \\ Science Agriculture and Engineering, Newcastle University, UK; ${ }^{\mathrm{d}}$ MRINA, independent \\ researcher. \\ *email: abdul.hannan@ncl.ac.uk
}

\begin{abstract}
The exponential growth of population and the consistent food demand has compelled humanity to seek alternatives to traditional farming and innovative technologies to increase production. Exploring offshore for natural resources and alleviating pressure on land has been an ongoing research field, especially in the energy and aquaculture sector. However, the idea of floating farming is still in its infancy and requires significant innovations. The work presented here shed further light on this area by proposing a comprehensive model of 'Integrated, multicultural, Multileveled Floating Farm (MFF).' Various aspects of planning, design, constructions and operations of such MFF are discussed. An integrated waste management system is proposed to improve sustainability. The conceptual design and associated financial analysis demonstrated that such integration of various modes of farming could be profitable and sustainable at the same time. The cost estimation and profit analysis are presented in the context of Singapore, and a conservative approach is followed for the calculation. However, the model can easily be extended for application in other countries.
\end{abstract}

Keywords: Floating farming; sustainable farming; Integrated farming; Multilevel Floating Farm 


\section{INTRODUCTION}

The global population is projected to grow to around 8.5 billion in 2030 [1], resulting in a rise of $50 \%$ in global food demand by that time [2]. As humanity is exhausting traditional natural resources to support present food demand, the exploitation of offshore for farming is one of the prime opportunities to sustain the future challenge. Several pilot projects are already developed around the world on floating farming, for example, the first floating dairy farm [3], conceptual design on vegetable farming [4], hydroponic and fish farming [5] [6]. However, none of these concepts considered the idea of a Multi-levelled integrated Floating Farm (MFF) by combining all the basics modes of farming.

Besides, to ensures sustainability and limit the overall footprint of human uses in the ocean, it is crucial to explore the possibility of integrating non-traditional farming techniques with alreadyexisting technologies. Therefore, this study considers the idea of an MFF by combining different farms (fish, vegetables, poultry and mushrooms) under one roof; and presents a comprehensive analysis of its design, construction, and operation in Singapore's context. This concept can also be extended for application in the SE region, especially in countries where land is scarce and has many competing users.

Singapore, as a city-state that imports more than 90 percent of its food, is exposed to the volatilities of the global food market, and the COVID19 pandemic has highlighted its needs for independent essential supplies like food and water. Singapore Food Agency (SFA) has recently set the target of producing 30 percent of the country's nutritional needs by 2030 [7]. This article has demonstrated that MFFs could be an efficient means of achieving that target. It can be profitable and sustainable at the same time, without stressing much on urban development and the environment. Starting with addressing the geographical and legal issues, this article presents conceptual development of the design of the MFF, construction cost and challenges, operational planning and financial estimations in the subsequent sections, and finally highlights the aspects of sustainability of the proposed MFF.

\section{GEOGRAPHICAL, POLITICAL, LEGAL AND FISCAL CHALLENGES}

There have been significant technological developments for offshore floating platforms, especially for floating renewable energy platforms. However, for floating agricultural farms, the analysis and forecasting of practical issues such as environmental impacts, jurisdictional matters, financial viability, and approvals are not yet available in the literature.

\subsection{International Legislation about Sea Usage}

The United Nations Convention on the Law of the Sea (UNCLOS) [8] is the main source of public international law that regulates the rights, duties and limits of national use of territorial waters, sea-lanes, and ocean resources. The Convention was signed in 1982 and came into force in 1994, ratified by more than 160 countries to date, including Singapore [9]. The Convention marked part of offshore water as Exclusive Economic Zone (EEZ - up to $370 \mathrm{~km}$ from shore), which a country could use for various economic purposes, including exploiting and regulating fishing, installation 
and construction of artificial islands and other floating facilities. Where the EEZs of neighboring countries overlap, a boundary line must be drawn by agreement to achieve an equitable solution. The total area of Singapore's exclusive economic zone (EEZ) is $714 \mathrm{~km}^{2}$ (Figure 1).

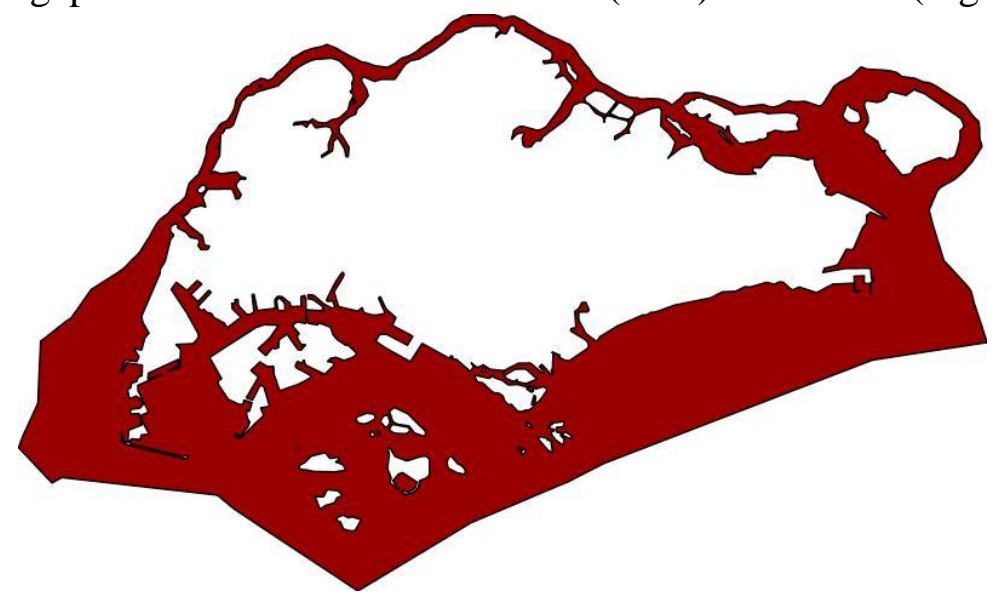

Figure 1. Singapore exclusive economic zone [10]

While UNCLOS lay down broad principles on various offshore water uses, the elaboration of these rules is handled by other treaties. For example, most of the shipping issues, prevention of pollution and environmental preservation are contained in several treaties adopted under the International Maritime Organization (IMO):

- International Convention for The Safety of Life At Sea (SOLAS),

- Convention on The International Regulations for Preventing Collisions at Sea (COLREG),

- The International Convention for The Prevention of Pollution from Ships (MARPOL),

- $\quad$ and many more.

Similarly, broad standards for fisheries conservation and the EEZ management are supplemented by nonbinding guidelines developed by the UN Food and Agriculture Organization, adopted in 1995. On the contrary, only a handful of such policies are available for floating farms (e.g. the Japanese legislation for Floating offshore wind farms [11], and explicit guidelines on floating food farms operations are not available in the literature, particularly for the Asian region.

\subsection{Location and availability of sea}

The whole area of Singapore EEZ cannot be used for farm installation due to navigational, security and political reasons. Some possibly permitted locations are shown in Figure 2, and the number of floating fish farms along the coasts of this EEZ is already established in the shallow depth ( 5-15 m) of Johor Strait [12]. However, plenty of spaces are still available, and with support from the local government (for example, a recent $\$ \$ 55 \mathrm{M}$ grant from Enterprise Singapore on boosting the local agrifood sector [7]), there lie good opportunities for the establishment of MFF in this region. 


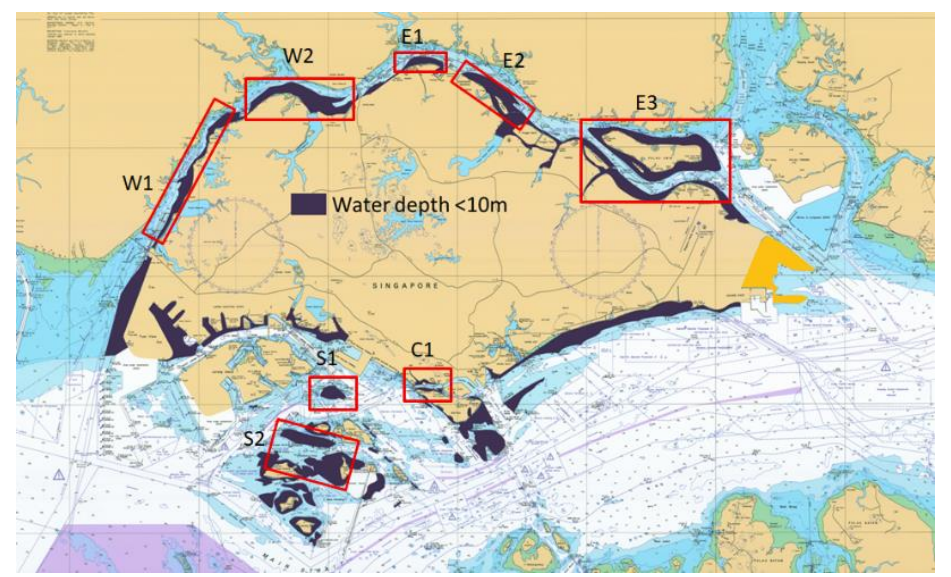

Figure 2. Suitable zones for MFFs around Singapore (Copyrights@ Jamesfong@gmaritime.com)

\subsection{Classification and Statutory Control}

All floating structures operating offshore need classification societies' approval. However, as the concept of offshore food farming is still new, none of the classification society offer complete \& established design codes to define various requirement and design criteria for floating food farms. For example, design, fabrication and testing of structures, stability and watertight integrity, marine machinery and equipment.

Nevertheless, development in this sector is ongoing, and several classification societies have already prepared rules for floating fish farms. For example, DNV-GL's code for Offshore fish farming units and installations [13], and ABS's guide for building aquaculture installations [14]. In addition, existing classification regulations for similar structures (offshore platforms/barges) can be adopted and further modified to ensure the safe operations of floating food farms. For example, DNVGL has regulations for "Non-self-propelled units," and the ABS has "Rules for Building and Classing Offshore Installations" and "Building and Classing of Steel Barges."

\subsection{Environment preservation/ limits of operation}

Industrial offshore floating farming comes with additional pressure on the marine environment, such as the level of pollution from discharged wastes/wasted water, disease control, dissolved oxygen in the water, imbalance of sea waters nutrient level, exhaust air and gases, noises and vibrations. To tackle these issues, UN FAO has developed the National Aquaculture Legislation Overview (NALO) [15] consisting of a series of comparative national overviews of aquaculture laws and regulations from the top 40 aquaculture producing countries. However, Singapore is not listed under those 40 countries.

Besides, Part XII of the UNCLOS [8] Convention specifies state obligation to protect and preserve the marine environment and highlights state duties consistent with these goals. Also, the Fisheries Act of UNCLOS, articles 61 and 62, regulates fishing in terms of the types of commercial activities 
allowed, types of licenses granted, scientific research, export of marine products, and usage of harmful substances. It is expected that Singapore will adopt some of these regulations soon as the offshore food farming activities increase in this region.

\subsection{Local Legislation of Sea Water Usage}

All of Singapore's regulations on prevention of pollution at sea and on shipping are set by the Maritime and Port Authority of Singapore (MPA) [16] following the provisions of international maritime conventions, to which Singapore is a party. For example, Singapore's Act of Parliament on 'Prevention of pollution of the Sea' [17] gives effect to the provisions of Annexes I, II and III of the MARPOL 73/78 convention, which aims to prevent sea pollution. Under UNCLOS, Singapore, as a coastal state, is also obliged to take care of any artificial islands, installations, and structures in its EEZ, including jurisdiction to customs, navigational, fiscal, health, safety and immigration laws and regulations. They are also obliged to establish reasonable safety zones of 500 meters around such installations, where necessary.

However, none of these rules covers all aspects of the potentially harmful effects of MFFs. Besides, no exclusive legislation related to MFFs or similar structures is found in the Singapore government's database for legislation. Although the above Acts can be revised and applied for development the of floating farming solutions, significant knowledge development in this area is still required.

\subsection{Government Approval of Project}

According to the MPA, any projects involving foreshore or marine development require approval from the Committee for Marine Projects (COMET). Type of projects includes, but are not limited to, installation of floating docks, floating restaurants, marine recreational facilities, fish farms [18]. Apart from such approval, the licensing for food farms in Singapore is controlled by the Singapore Food Agency (SFA), and the license is renewable on an annual basis.

Floating farming has gained significant attention across various sectors, including local governmental organizations, international authorities, classification societies and insurance providers. However, the coordination among various bodies is scattered, customized and projectspecific rather than streamlined, as compared to other types of conventional floating structures. It is expected that over the coming years, this process will be shaped into the much-needed complete framework for offshore floating farming. 


\section{HYDROGRAPHICAL CONSIDERATIONS}

Knowledge of environmental aspects is crucial for the design and operation of any locationspecific floating structures. Fortunately, the naturally protected (Malaysia in North and Indonesia with many small islands in the South) vast coastline of Singapore provides a safe harbor environment suitable for safe operations of MFFs, compared to many other places around the world.

\subsection{Wave}

Due to its sheltered geography, significant wave heights around Singapore are typically lower than $1 \mathrm{~m}$. An estimated $10 \mathrm{Yr}$. return period significant wave height is approx. 1 meter and for $100 \mathrm{Yr}$. return period, it is around 1.2 meters [19]. Besides, on a seasonal basis, a maximum significant wave height of approx. $0.3 \mathrm{~m}$ and of $0.35 \mathrm{~m}$ is observed during the southwest and the northeast monsoon season, respectively. The heights generally decrease to approx. $0.1 \mathrm{~m} \mathrm{[19]} \mathrm{during} \mathrm{inter}$ monsoon periods. Such small wave heights are not expected to contribute to structural or mooring loads for the MFF significantly. However, it may still affect the logistic operations throughout the year.

\subsection{Wind}

The prevailing winds are Northerly to North-easterly and South to South-easterly for Northeast and Southwest monsoon, respectively. Generally, the winds in Singapore are light, with the mean surface wind speed usually less than $2.5 \mathrm{~m} / \mathrm{s}$. However, during the Northeast Monsoon, a wind speed of $20 \mathrm{~m} / \mathrm{s}$ or more may be observed [20]. The 1-hour average, 10 Year Return Period winds speed can go up to $11.5 \mathrm{~m} / \mathrm{sec}$. For this project, the MFF will have a large windage area; therefore, the wind load will significantly impact total mooring loads.

\subsection{Current}

Due to several islands and shipping routes, the directionality and magnitude of current around Singapore water vary significantly. In the open waters of the Singapore Straits, the tidal speed can vary from $0.5-1 \mathrm{~m} / \mathrm{sec}$ and may increase to $1.5-2.0 \mathrm{~m} / \mathrm{sec}$ in constricted channels between the islands [21]. The wind-generated non-tidal current can attain a maximum speed of $0.4 \mathrm{~m} / \mathrm{s}$ during the North-East monsoon. Although the overall range is relatively low, the current speed of $2 \mathrm{~m} / \mathrm{sec}$ may play a significant part in the MFF's mooring loads.

\subsection{Water Depth \& Tides}

The water depth of the Singapore Strait ranges between $20 \mathrm{~m}$ and $120 \mathrm{~m}$ (Figure 3 ). The blue and green zones $(20-40 \mathrm{~m})$ represent interest areas suitable for MFF (subject to approval). Tidal variation in the Singapore Strait is usually generated by tidal waves from the South China Sea and the Indian Ocean, and it ranges from 2.5-3.0 m during spring to 0.7-1.2 $\mathrm{m}$ during neap [21]. However, as demonstrated later, the nature of the proposed MFF design makes it indifferent to tidal variations. 


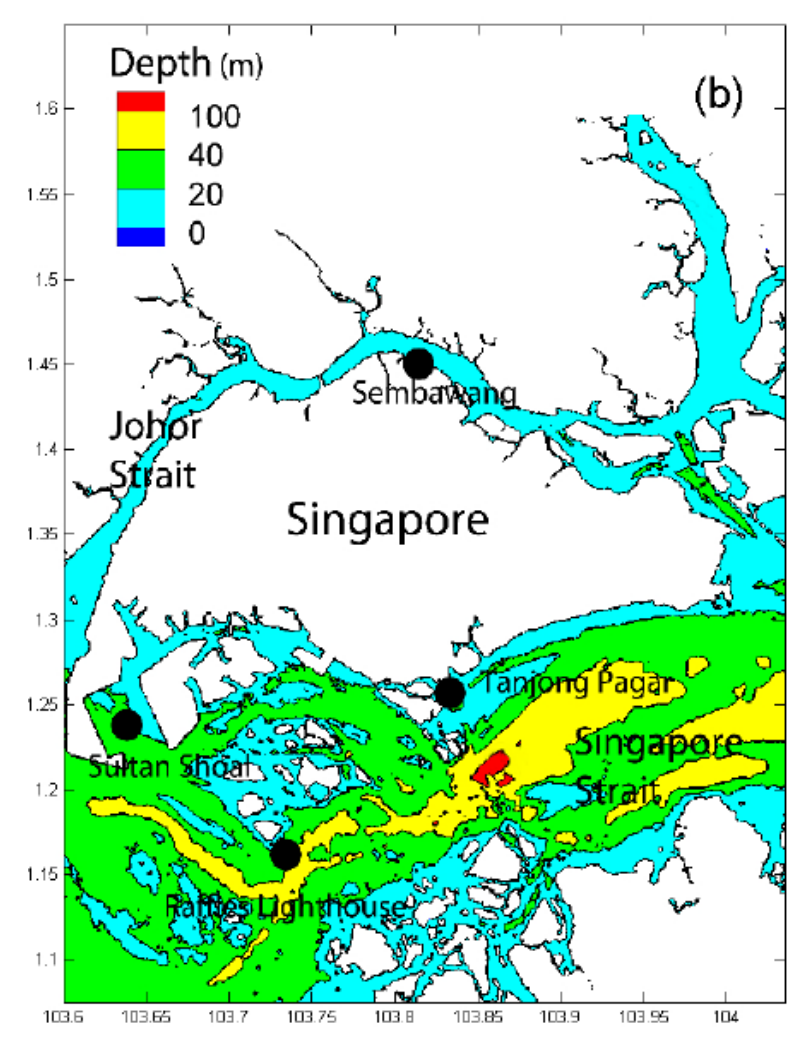

Figure 3. The Singapore Strait and its vicinity (bathymetric contours are at 20, 40 and 100m depths) [22]

\section{CONCEPTUAL DESIGN}

It should be noted here that the images and analysis presented in subsequent sections do not represent actual design work but are based on certain assumptions and extrapolation. All parameters are obtained based on a conservative estimation of various published data, which are normalized for the present application. Also, the combinations of farms, integration of modules and related artworks are provided only to illustrate the basic principle of the MMF and subjected to project-specific amendments as required. All costs are in Singapore Dollars (1.0 USD=1.38 SGD).

\subsection{Design Philosophy}

A modular and scalable MFF with six floors is proposed in this study, where each level is an independent, self-contained module, and the number of levels can be increased or reduced to suit the market demand. Such vertical and modular integration will ensure increased production, cost-sharing and smart waste management, as demonstrated later. The maximum overall height and number of vertical levels will be governed by stability and motions of the floating body. 
The MFF can be divided into two major parts (Figure 4Figure ) :



Figure 4. Major components of MFF

All Farm's requirements for power, water, $\mathrm{CO}_{2}$, ventilation and refrigeration are self-contained and independent from shore supply (unless it is specifically required).

\subsection{Material of Construction}

Concrete is suitable for modular construction and has widely been used with economies of scale. It has several advantages, such as lower fabrication \& maintenance costs and longer life. However, steel is the traditional material, readily available from many shipyards around Singapore, and if only one or two units need to be fabricated, the steel will be a cost-effective solution. Therefore, in this study, steel is selected as the material for the pontoon and superstructure.

\subsection{Floater \& Farms' Design}

\subsubsection{Floater}

Considering the size of farms presently used for hydroponics and fish farming and with a constrain to keep the overall project cost reasonable for commercial investors, a footprint of $60 \mathrm{~m} \mathrm{x} 60 \mathrm{~m}$ is proposed. This gives an area of 3600m2 ( 0.9 acres) for each level. The total footprint at each level is divided into two zones: a Productive area $\left(\sim 3200 \mathrm{~m}^{2}\right)$ for farming and related activities and a Core $\left(\sim 400 \mathrm{~m}^{2}\right)$ in the center for stores, processing and administrative activities. Each level is $6 \mathrm{~m}$ high to accommodate any requirements for Vertical farming, except the lowest level (\#0-pontoon), which has a height of $9 \mathrm{~m}$, including a $3 \mathrm{~m}$ high Double bottom (Figure 5Figure ). 


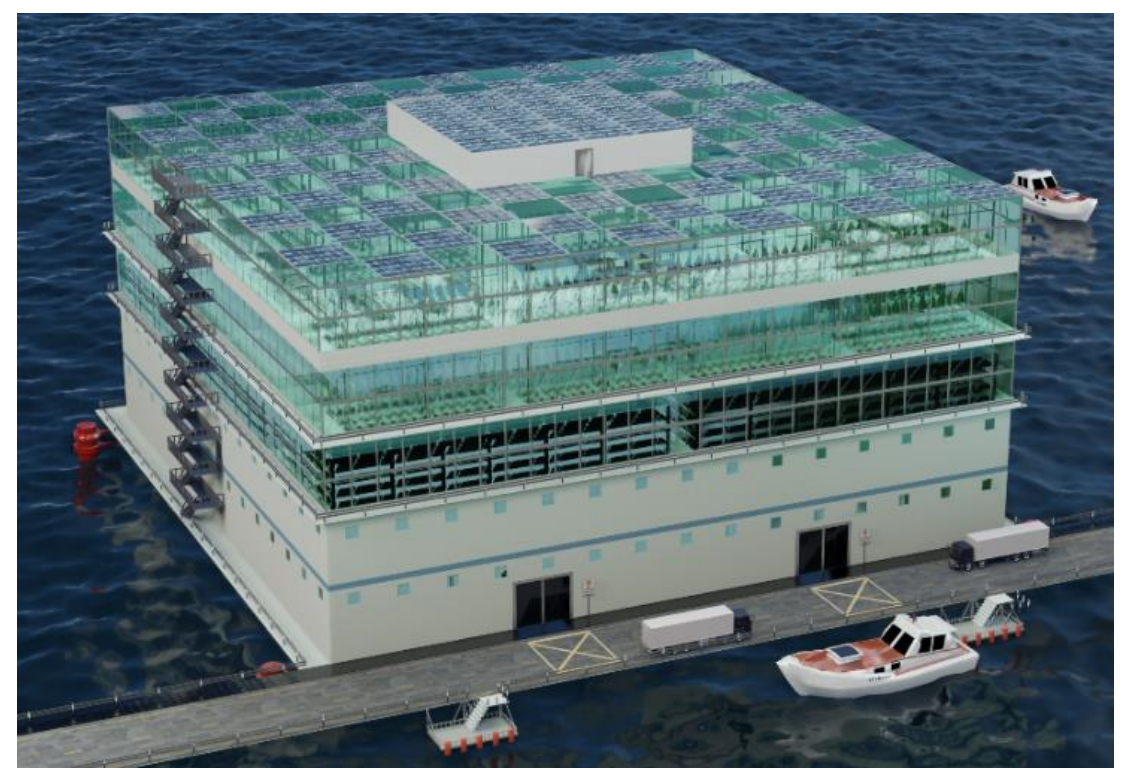

Figure 5. Overall 3D view of the Proposed Multi-level Floating Farm (MFF)

The Core area of each floor could be separated into two levels of equal 3 m heights: the Lower Core (on the same level with Production zone) assigned for cold stores, farming equipment and processing areas, and Upper Core for offices, cabins, utility and changing rooms, etc. (Figure 6). Upper Core is an optional choice (not included in the rental cost calculation); it may not be required if MFF is located close to shore and/or used by a single Owner/Tenant. However, Upper Core will be beneficial if MMF is far enough from the shore to justify permanent crew on board or separate tenants lease each floor.

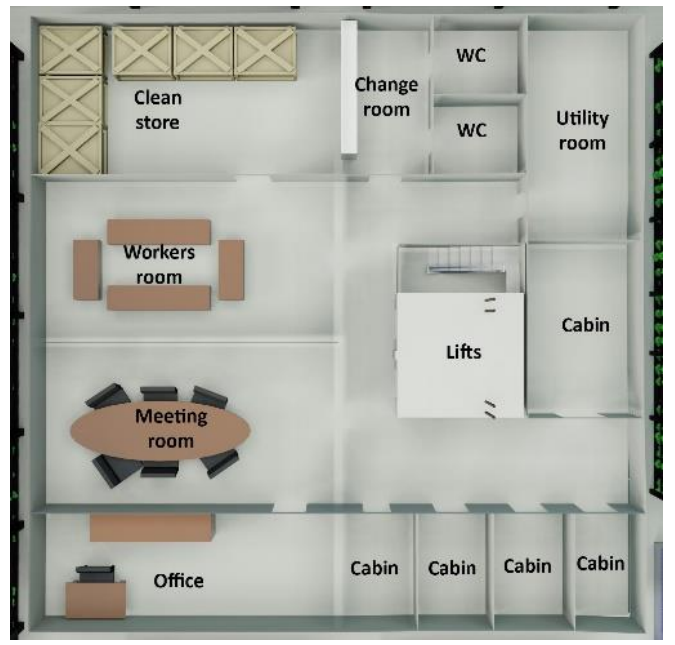

(a)

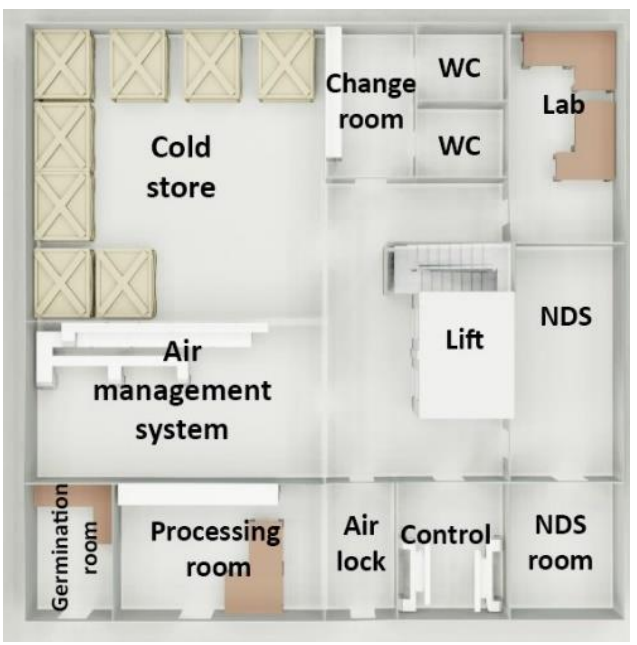

(b)

Figure 6. Arrangement of typical Upper (a,) and Lower Core (b) areas

Main vertical access between levels is provided with 2 elevators and a staircase (level \#0 to rooftop) located inside the Core area. The secondary escape ways are also provided as required by regulations. The MFF as a floater will not be affected by tides and will have low wave impact as it is installed 
in a sheltered area of Singapore waters. As a result, the main deck is designed to be $2 \mathrm{~m}$ above the sea level, but this height can be adjusted according to the severity of the environments. An estimated CAPEX for the floater is shown in Table 1.

Table 1. CAPEX estimation for floater with machinery

\begin{tabular}{|l|l|}
\hline Floater only & \\
\hline Hull Steel & $\$ 17,980,000$ \\
\hline Steel Outfitting & $\$ 3,222,180$ \\
\hline $\begin{array}{l}\text { Mechanical Equipment (incl. LNG Power } \\
\text { Generator) }\end{array}$ & $\$ 6,300,000$ \\
\hline $\begin{array}{l}\text { Elec equipment (incl. SWBDs, XFMRs and } \\
\text { distribution boards) }\end{array}$ & $\$ 2,100,000$ \\
\hline Elec Bulk & $\$ 705,625$ \\
\hline Piping \& pipe bulk & $\$ 424,000$ \\
\hline Architectural & $\$ 625,000$ \\
\hline Paint & $\$ 100,000$ \\
\hline Total CAPEX & $\mathbf{\$ 3 1 , 4 5 6 , 8 0 5}$ \\
\hline
\end{tabular}

\subsubsection{Double Bottom and Level\#0 Fish Farming}

Double bottom is a fully submerged section of the pontoon with $3 \mathrm{~m}$ height, which has a total of $10,800 \mathrm{~m}^{3}$ volume (increasable) and contain various tanks for ballast water (to adjust the draft and trim/ heel angles), freshwater, fuel, sewage, wastewater, drain/sludge, etc. (Figure 7).

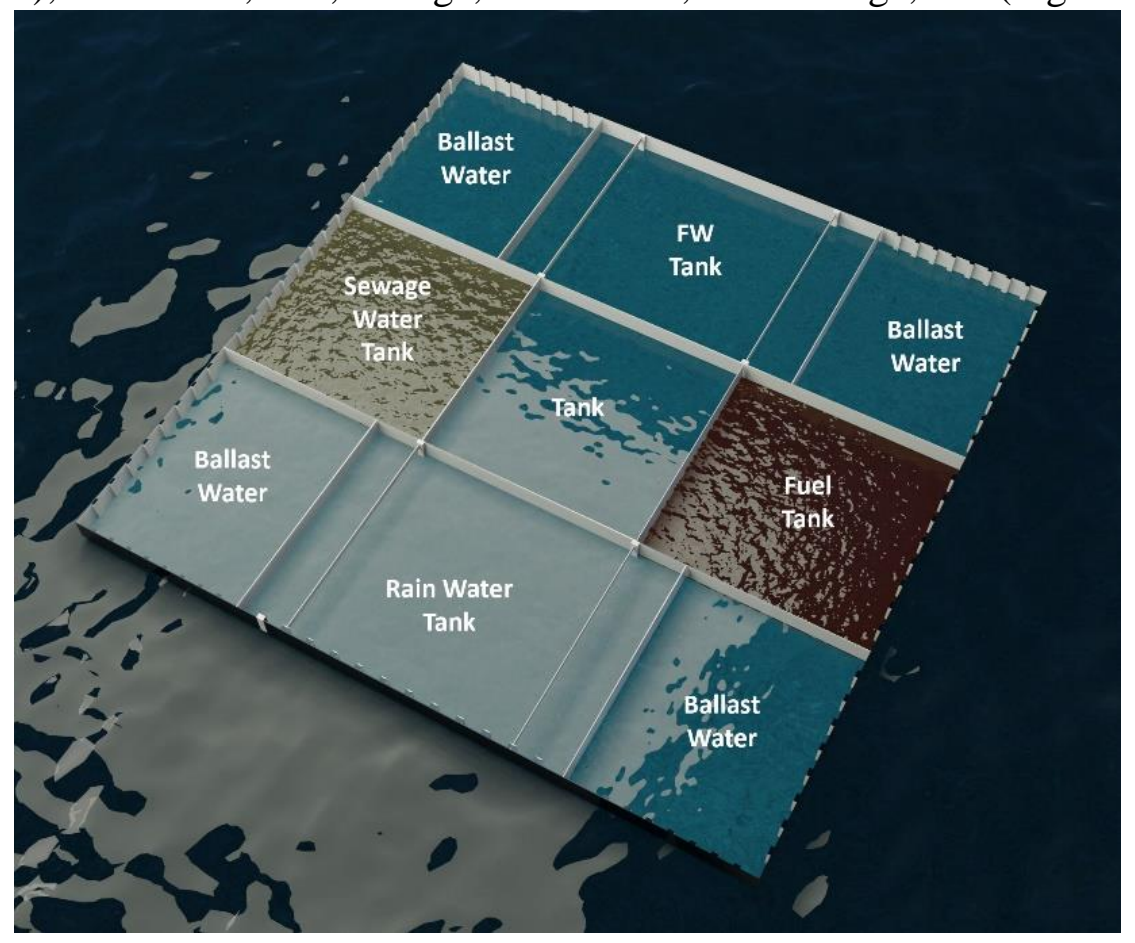

Figure 7. Typical Double bottom arrangement 
Above the Double bottom is the Fish farm, which is subdivided by watertight (WT) bulkheads, equipped with WT doors to provide WT integrity of the floater. Aside from necessary fish farming equipment, some of the floater's main machinery, such as Power generator, FW generator, ballasting system, etc. will also be located at this level (Figure 8). Fuel tank shown in Figure 7 is MDO, however, in case of LNG usage, special tank for LNG to be arranged in the same location.

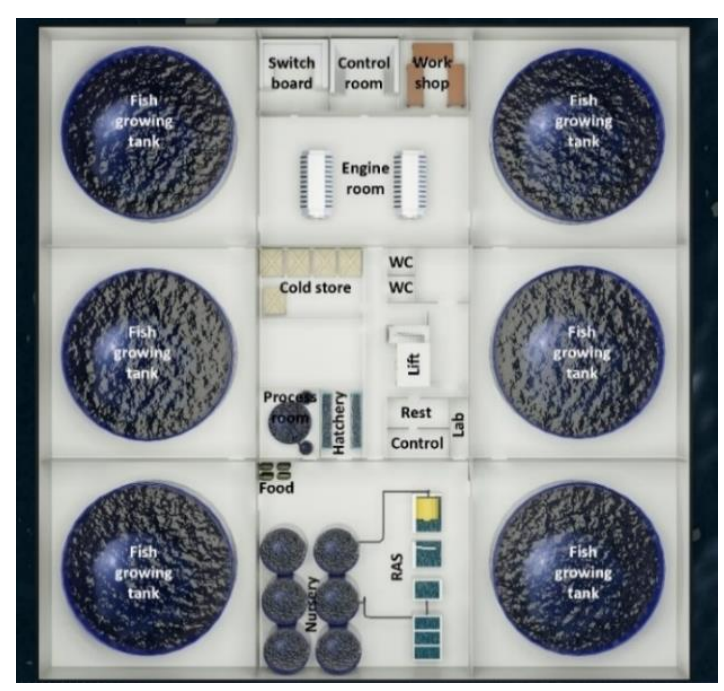

(a)

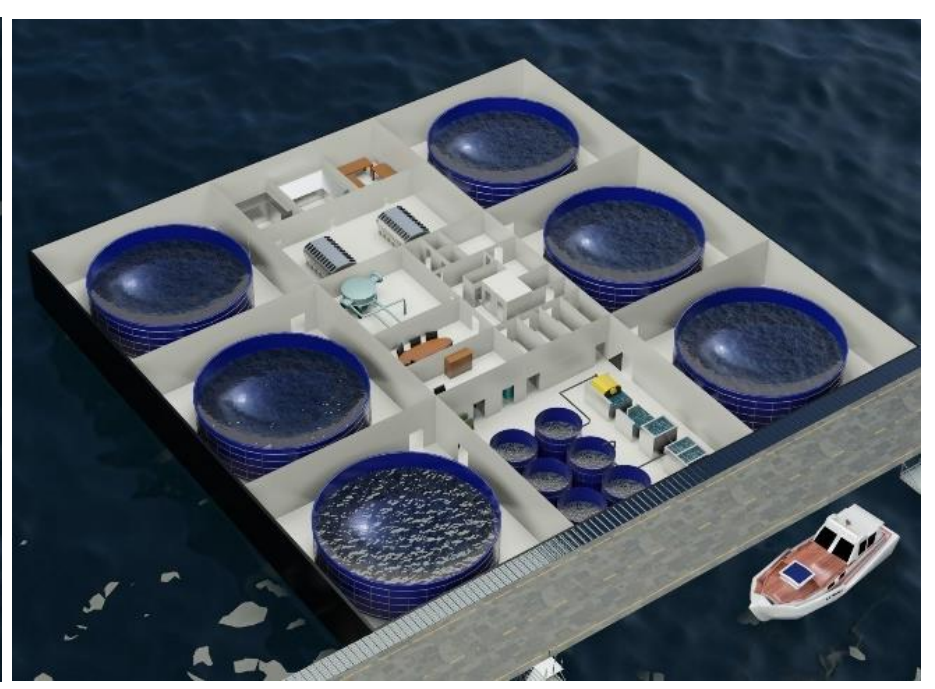

(b)

Figure 8. Arrangement of Level \#0: a) Plan and b) 3D view

The fish farm includes 6 fish tanks ( $17 \mathrm{~m}$ dia by $4.5 \mathrm{~m}$ height) as the main grow-out system with an approximate total volume of $6000 \mathrm{~m}^{3}$. There will also be a hatchery, nursery, filtration systems, feeding and control systems, pumps and processing room (Figure 9). A closed containment freshwater Recirculating Aquaculture Systems (RAS) is assumed for the fish farming [23] while calculating the data in Table 2

Table 2. Fish production of Level \#0

\begin{tabular}{|l|l|l|}
\hline Total tanks volume & 6,128 & $\mathrm{~m} 3$ \\
\hline Fish density & 16 & fish/m3 \\
\hline Total fish No & 98,055 & fish \\
\hline Rate Yield, per m3 per year & 80 & $\mathrm{~kg} / \mathrm{m} 3 /$ year \\
\hline Total annual fish production & 490,277 & $\mathrm{~kg}$ \\
\hline Power supply, $\mathrm{kWh} / \mathrm{kg}$ of fish & 5.46 & $\mathrm{kWh} / \mathrm{kg}$ of fish \\
\hline Total annual power consumption, & $2,676,912$ & $\mathrm{kWh} /$ year \\
\hline Total Annual Water consumption & 421,168 & $\mathrm{~m} 3 /$ year \\
\hline
\end{tabular}




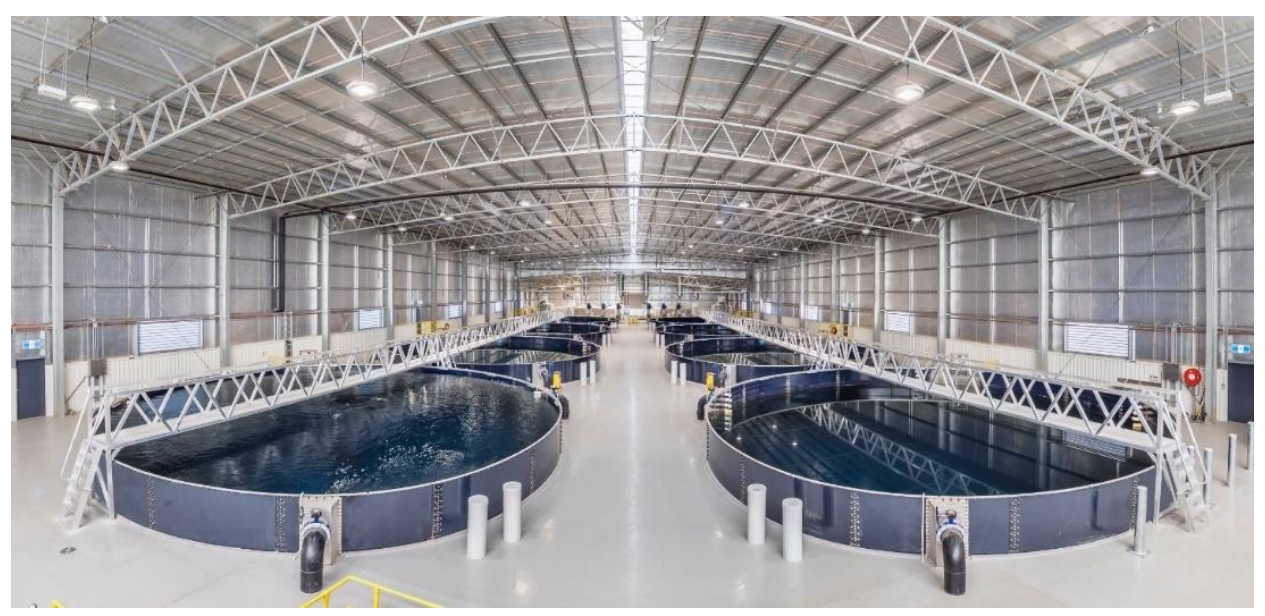

Figure 9. Typical Fish Farm [24]

Table 3 shows the estimated CAPEX for the fish farm. The break-even price for production of fish in this conservatively estimated study is found to be $\$ 8.0-8.5 / \mathrm{kg}$, comparing with the average wholesale prices on the Singapore market, the cheapest Sea bass and Grouper are about $\$ 8 / \mathrm{kg}$, while White Pomfret and Golden Snapper can be up to $\$ 15-19 / \mathrm{kg}[16]$.

Table 3. CAPEX for Fish Farm

\begin{tabular}{|l|l|}
\hline RAS Systems & $\$ 4,674,422$ \\
\hline Effluent treatment & $\$ 874,180$ \\
\hline Water supply & $\$ 169,196$ \\
\hline Engineering & $\$ 1,273,603$ \\
\hline Construction management & $\$ 265,334$ \\
\hline Process/packing eq- $\mathrm{t}$ & $\mathbf{\$ 5 2 9 , 4 0 3}$ \\
\hline Total CAPEX & $\mathbf{\$ 7 , 7 8 6 , 1 3 9}$ \\
\hline
\end{tabular}

\subsubsection{Level \#1 Loading Bay and Mushroom production}

Level\#1 on the Main deck provides space for some of the floater's machinery (HVAC, Control room, stores and workshops, etc.), canteen, processing, general stores for all farms/products (including cold stores) and loading/unloading bay. The total area of the Main deck is assumed to be bigger than pontoon to provide open-deck platforms for transportation of cargo, quay/landing zone, road, security walkways, etc. Logistics will depend on the location of MFF with regards to the shore. It could be by a floating bridge linked to the shore or by using supply barges to dedicated quay/wharf (Figure 10).

Half of the Level\#1 is used for mushroom production, which is characterized as a low cost/low maintenance system, as it has a low electricity demand (dim light/darkness), growing media (mostly organic wastes, for example, composted manure, straw, corn cobs, peanut shells, leaves, 
logs, sawdust), and water supply needs. The mushroom farm could also utilize part of the Production areas of hydroponic farms (Level\#3\&4) that lacks sunlight (dark zones in central areas). If the resultant cost of electricity makes it economically inefficient to grow vegetables in such zones, it could be separated and modified for mushroom growing.

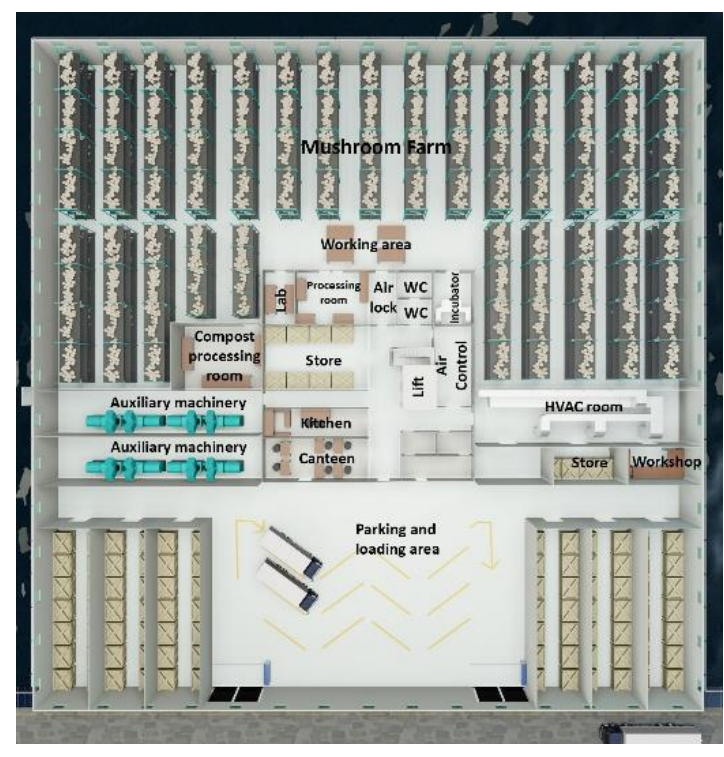

(a)

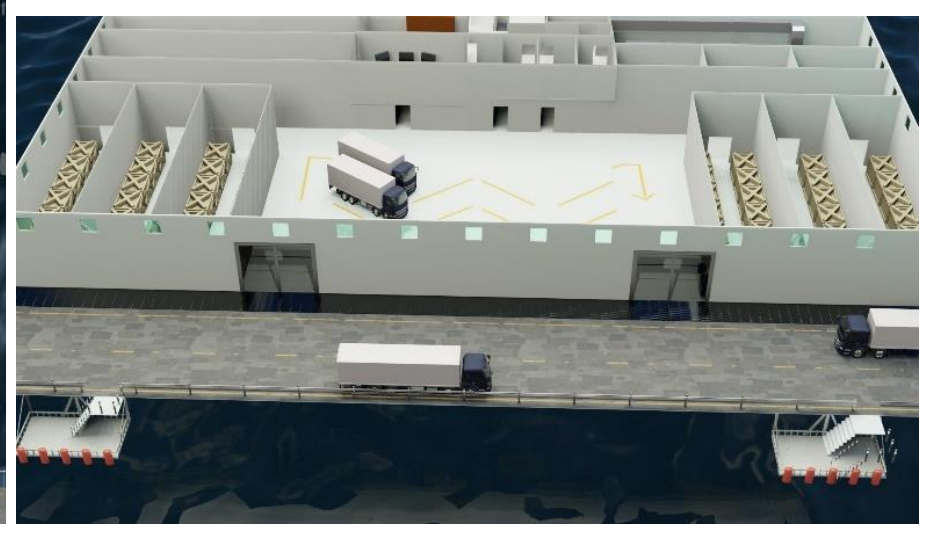

(b)

Figure 10. Arrangement of Level \#1-a) Plan and b) 3D sectional view.

Considering Singapore's tropical climate, commercial mushrooms, such as Oyster mushroom Pleurotus ostreatus, Shiitake mushrooms Lentinus edodes, Volvariella volvacea, and paddy straw mushroom are found suitable for cultivation as they could fruit at $25-30^{\circ} \mathrm{C}$ (Figure 11). Among these, the Oyster Mushroom cultivation system [25] [26] are considered for the estimation presented in this study (Table 4).

Table 4. Mushroom Production of Level \#1

\begin{tabular}{|l|l|l|}
\hline Total production area footprint $(0.8)$ & 1280 & $\mathrm{~m} 2$ \\
\hline Number of layers/ tiers per rack & 2 & \\
\hline Total production/growing area & 2560 & $\mathrm{~m} 2$ \\
\hline Plant per $\mathrm{m} 2$ & 40 & $\mathrm{plant} / \mathrm{m} 2$ \\
\hline Total Plants & 102400 & $\mathrm{plant}$ \\
\hline Harvest per $\mathrm{m} 2$ & 48.53 & $\mathrm{~kg} / \mathrm{m} 2 / \mathrm{year}$ \\
\hline Harvest cycle & 60 & days \\
\hline Yield/harvest & 20,480 & $\mathrm{~kg} / \mathrm{cycle}$ \\
\hline Annual harvest & 124,245 & $\mathrm{~kg} /$ year \\
\hline Total annual power consumption & 120,468 & $\mathrm{kWh} /$ year \\
\hline Total water circulation & 1303 & $\mathrm{~m} 3 /$ year \\
\hline
\end{tabular}




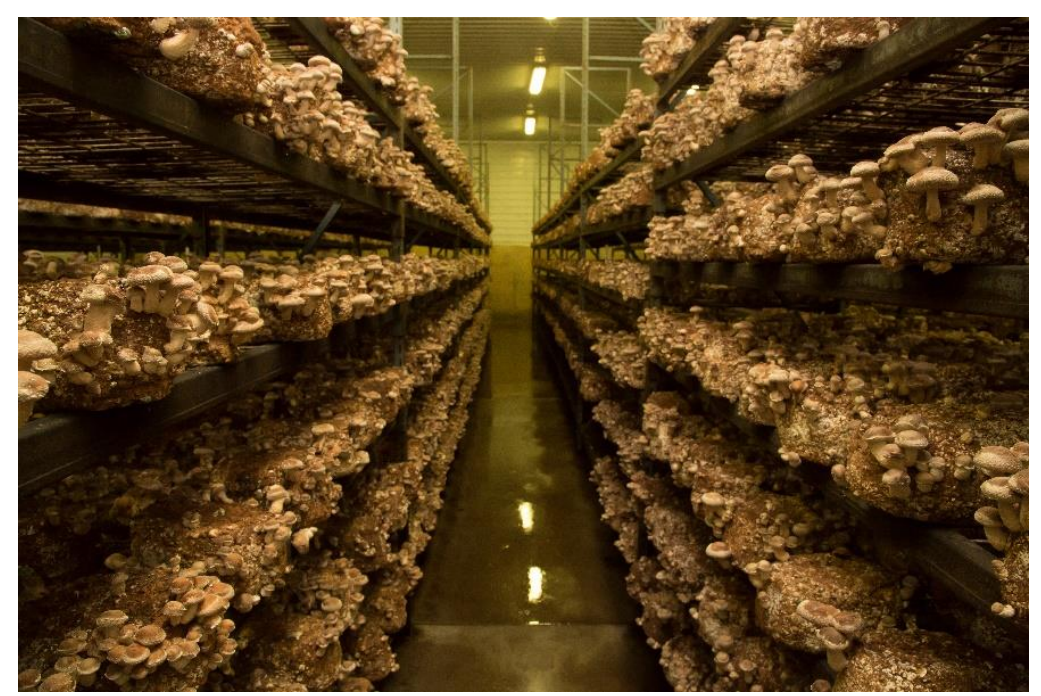

Figure 11. Typical Mushroom Farm [27]

The CAPEX for Mushroom Farm is presented in Table 5, and the break-even price for mushroom production is obtained as $\$ 5.5-6.0 / \mathrm{kg}$ based on a conservative estimate. Whereas the retail prices for fresh white Button, Shitake and Oyster mushroom are found to be $\$ 16-21 / \mathrm{kg}, \$ 9.8-22.0 / \mathrm{kg}$ and $\$ 7.5-14 / \mathrm{kg}$, respectively, in the Singapore market. [28]

Table 5. CAPEX for Mushroom farm

\begin{tabular}{|l|l|}
\hline Mushroom eq- $\mathrm{t}$ & \multirow{2}{*}{$\$ 20,000$} \\
\cline { 1 - 1 } Illumination eq- $\mathrm{t}$ & \\
\cline { 1 - 1 } Environment/ Health Control eq- $\mathrm{t}$ & \\
\cline { 1 - 1 } HVAC system & $\$ 15,349$ \\
\cline { 1 - 1 } Core/process/packing eq- $\mathrm{t}$ & $\mathbf{\$ 3 5 , 3 4 9}$ \\
\hline Total CAPEX & \\
\hline
\end{tabular}

\subsubsection{Level \#2 Egg/poultry farm}

Level\#2 is designed for egg-producing poultry farms as an example of possible integration in the proposed MFF. Integrated indoor cage egg production system [29] is selected as a prototype as the most advanced enterprise, involving full mechanization and automation of the egg production cycle, including battery egg-laying, temperature controls, scientific feeding and mechanized egg collection methods (Figure 12 \& Figure 13). Table 6 shows the details for the poultry farm estimated based on extrapolation. 


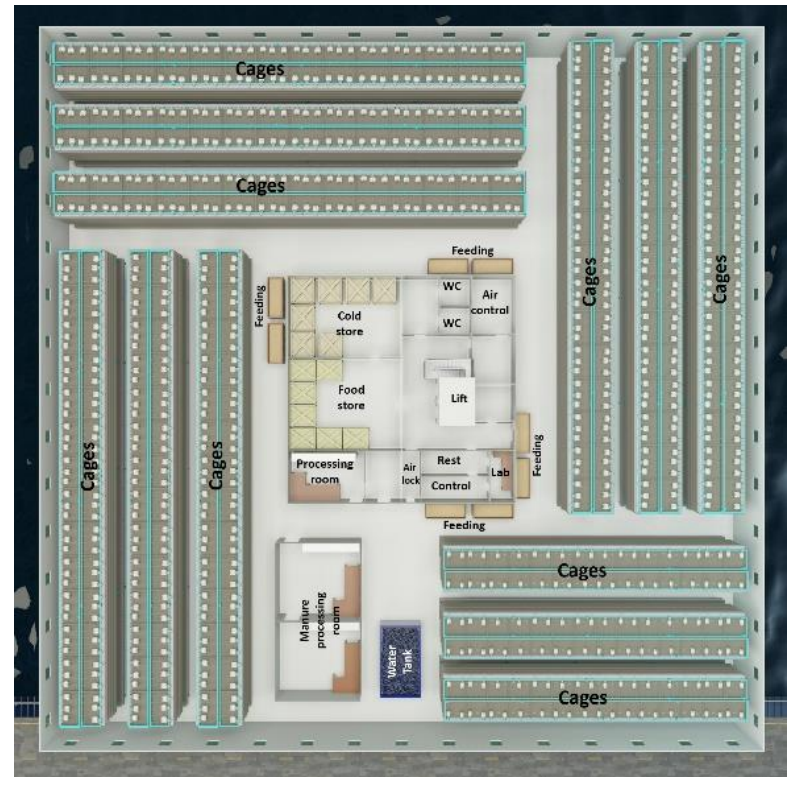

(a)

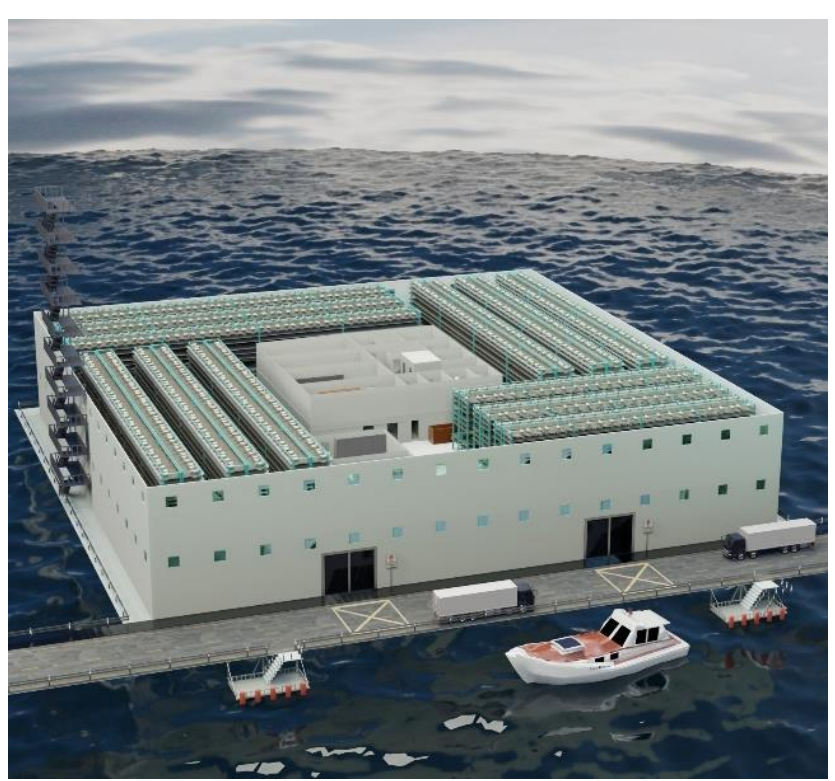

(b)

Figure 12. Arrangement of Level \#2- a) Plan and b) 3D section view

Table 6 Egg production of Level \#2

\begin{tabular}{|l|l|l|}
\hline Total rearing area footprint (0.6) & 1,920 & $\mathrm{~m} 2$ \\
\hline Number of layers/ tiers per rack & 6 & \\
\hline Total rearing area & 11,520 & $\mathrm{~m} 2$ \\
\hline Cage capacity, 1 tier & 5 & $\mathrm{birds} / \mathrm{m} 2$ \\
\hline Total Birds & 57,600 & $\mathrm{birds}$ \\
\hline Pre-lying cycle, & 180 & days \\
\hline Cycle, days & 385 & days \\
\hline Annual egg production & $9,644,544$ & $\mathrm{egg} / \mathrm{year}$ \\
\hline Annual manure production & $1,356,048$ & $\mathrm{~kg} /$ year \\
\hline Annual feed & $2,306,304$ & $\mathrm{~kg} /$ year \\
\hline Annual power consumption & $2,096,640$ & $\mathrm{kWh} / \mathrm{year}$ \\
\hline Annual Water consumption & 20,966 & $\mathrm{~m} 3 /$ year \\
\hline
\end{tabular}

The temperature inside the farm shall be maintained at $25-26^{\circ} \mathrm{C}$ to provide the most comfortable condition for egg-laying. This will require additional cooling/HVAC power. The Core area is provided with airlocks to avoid air contamination and soundproof insulation. 


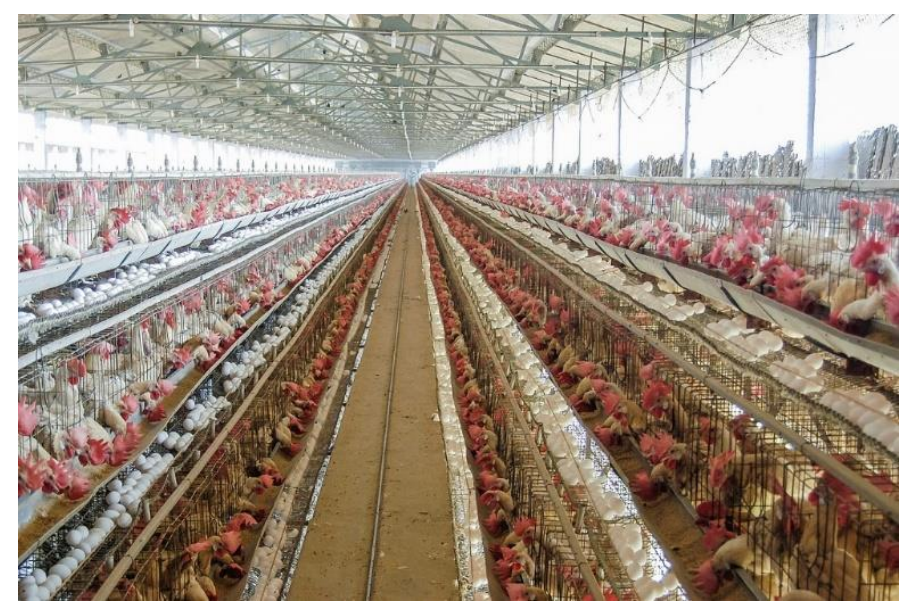

Figure 13. Typical Poultry Farm, [30]

The Break-even price for egg production obtained based on the CAPEX estimation in Table 7 is $\$ 1.8-2.0 / 10$ eggs, which is within the range of the current retail price of \$1.5-3.95/10eggs [28]

Table 7. CAPEX for Poultry farm

\begin{tabular}{|c|c|}
\hline Cages/ housing & \\
\hline Equipment & \\
\hline Lights & \\
\hline Water supply & \\
\hline Feeding system & \\
\hline HVAC system & \\
\hline Manure removal equipment & \\
\hline Egg collection & \\
\hline Environment/ Health Control eq- $\mathrm{t}$ & \\
\hline Process/packing eq-t & \\
\hline Total CAPEX & $\$ 3,100,000$ \\
\hline
\end{tabular}

\subsubsection{Level \#3 Leafy greens (lettuce) indoor}

Level\#3 contains indoor leafy green hydroponic, and the floor height of $6 \mathrm{~m}$ is sufficient to accommodate a vertical farming model [31], with multiple layers/tiers of plants to increase the productivity of each level. Bigger windows/transparent walls are used at this level for better sunlight penetration.

A vertical indoor gutter system lettuce cultivation [31] is assumed in this study and extrapolated to obtain the data in Table 8. The system includes Nursery, Germination room, Cultivation zone, Nutrient Delivery System (NDS), lights with racks, electrical distribution, HVAC/air management system, health and environment monitoring system, processing room, etc. (Figure 14). 


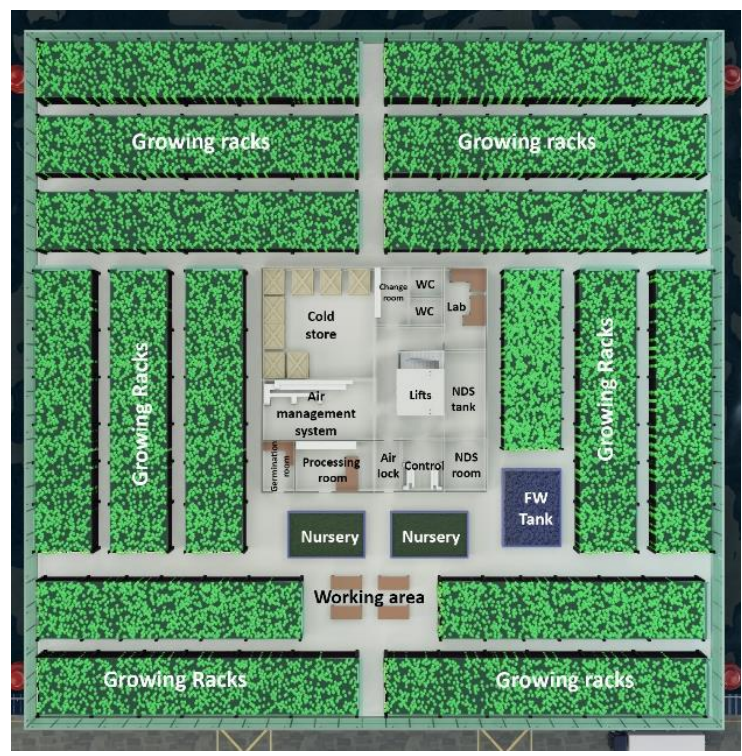

(a)

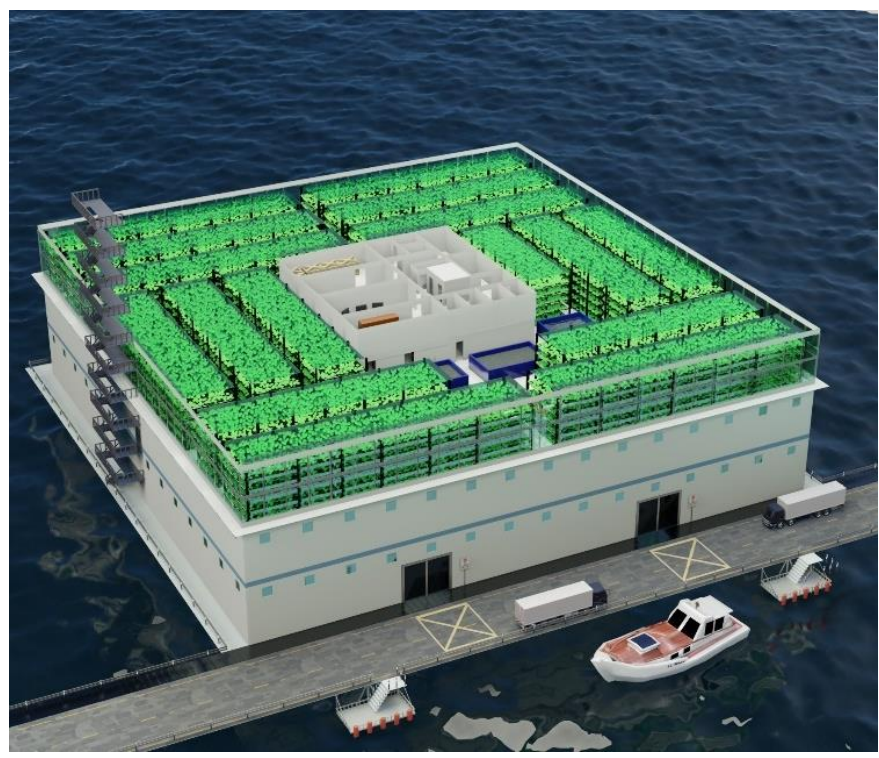

(b)

Figure 14. Arrangement of Level \#3: a) Plan and b) 3D sectional view

Table 8. Lettuce production of Level \#3

\begin{tabular}{|l|l|l|}
\hline Total production area footprint $(0.8)$ & 2560 & $\mathrm{~m} 2$ \\
\hline Number of layers/ tiers per rack & 4 & \\
\hline Total production/growing area & 10240 & $\mathrm{~m} 2$ \\
\hline Plant per m2 & 33 & $\mathrm{plant} / \mathrm{m} 2$ \\
\hline Total Plants & 337920 & $\mathrm{plant}$ \\
\hline Harvest cycle & 25 & days \\
\hline Annual harvest & 984,023 & $\mathrm{~kg} / \mathrm{year}$ \\
\hline Annual Inedible mass, & 836,420 & $\mathrm{~kg} /$ year \\
\hline Annual Nutrients solution & $2,938,752$ & $\mathrm{~kg} / \mathrm{year}$ \\
\hline Annual power consumption & $10,308,149$ & $\mathrm{kWh} / \mathrm{year}$ \\
\hline Annual water circulation & 74,547 & $\mathrm{~m} 3 /$ year \\
\hline
\end{tabular}

The cultivation zone contains growing racks ( $5 \times 5 \mathrm{~m}$ each with various length) with growing media along with the windows, divided into 4 levels, each 1 meter high and equipped with the plant cultivation gutters, LED lights, irrigation and runoff drain pipes for water circulation (Figure 15). Indoor hydroponics are typically noted for remarkably high electricity consumption. Following the CAPEX estimation in Table 9, the break-even price for lettuce is found to be $\$ 3.5-4.0 / \mathrm{kg}$, while the current retail price in Singapore is within the range of $\$ 6-13 / \mathrm{kg}$. [32] 


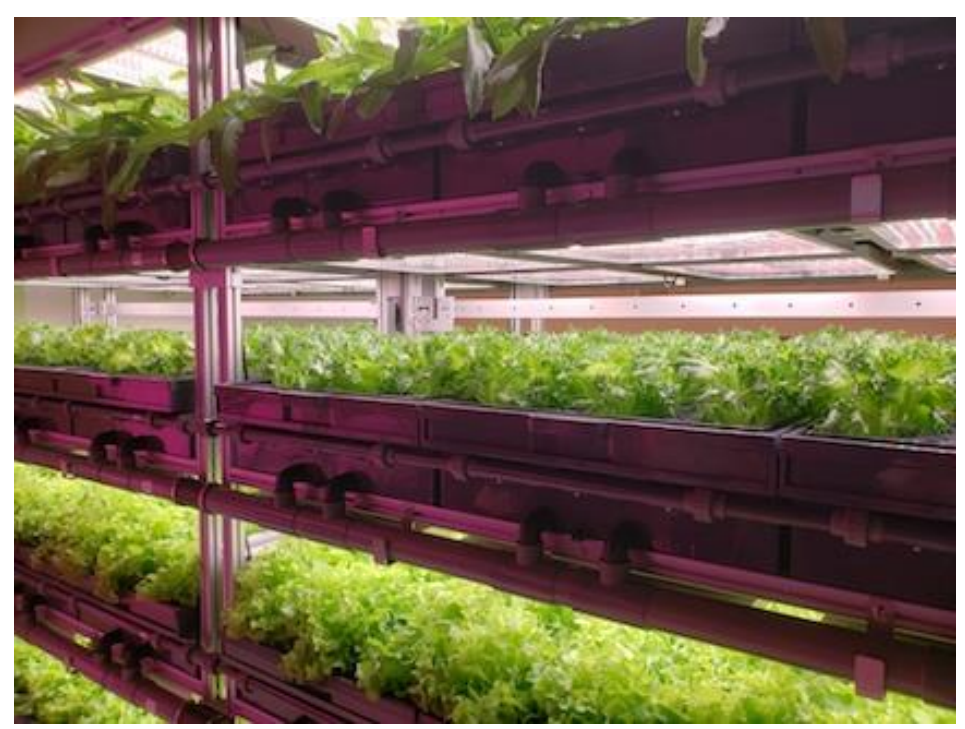

Figure 15. Example of leafy green system [33]

Table 9. CAPEX for Lettuce Farm Level \#3

\begin{tabular}{|l|l|}
\hline Horticulture eq- $\mathrm{t}$ & $\$ 2,876,144$ \\
\hline Hydroponic system & $\$ 468,058$ \\
\hline Illumination eq- $\mathrm{t}$ & $\$ 4,329,701$ \\
\hline Environment/ Health Control eq- $\mathrm{t}$ & $\$ 69,041$ \\
\hline HVAC system & $\$ 524,970$ \\
\hline Core/process/packing eq-t & $\$ 51,200$ \\
\hline Total CAPEX & $\mathbf{\$ 8 , 3 1 9 , 1 1 5}$ \\
\hline
\end{tabular}

\subsubsection{Level \#4 High wire vine crop (tomato) indoor}

Level\#4 contains high wire vine crop/ tomato indoor hydroponic. Similar bigger windows/transparent walls arrangements as per Level\#3 are used for this level also (Figure 16).

The cultivation zone of the vine crop module contains a conventional indoor high wire system with artificial lights and trellising wires reaching up to a maximum height of $3 \mathrm{~m}$ for each layer. The distribution of the LED lights includes two levels of intra-canopy lighting and one level of top lights. The maximum distance between the plants and the top LED lights is 1 meter. Indoor hydroponics are typically noted for very high electricity consumption. A vertical indoor High wire vine crop system cultivating cherry tomatoes [31] is considered and extrapolated in this study to reach the details presented in Table 10. 


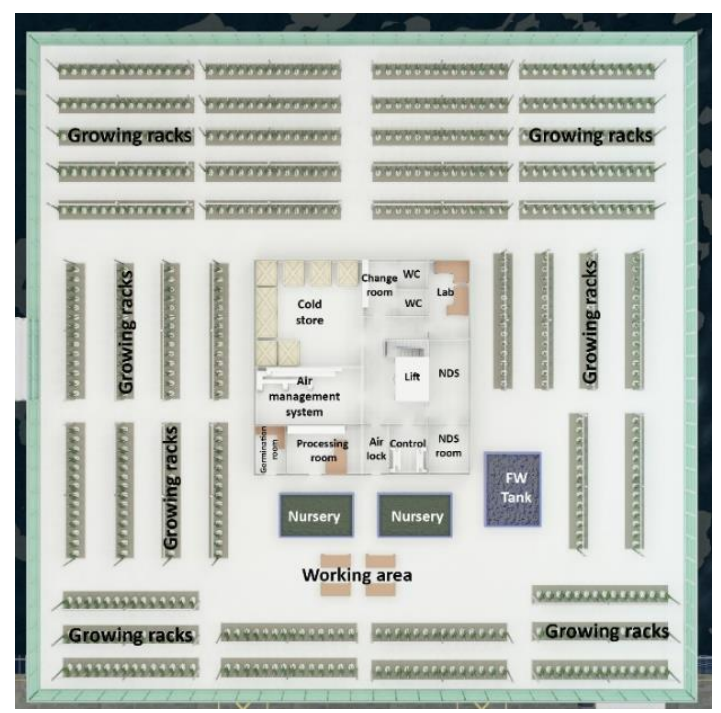

(a)

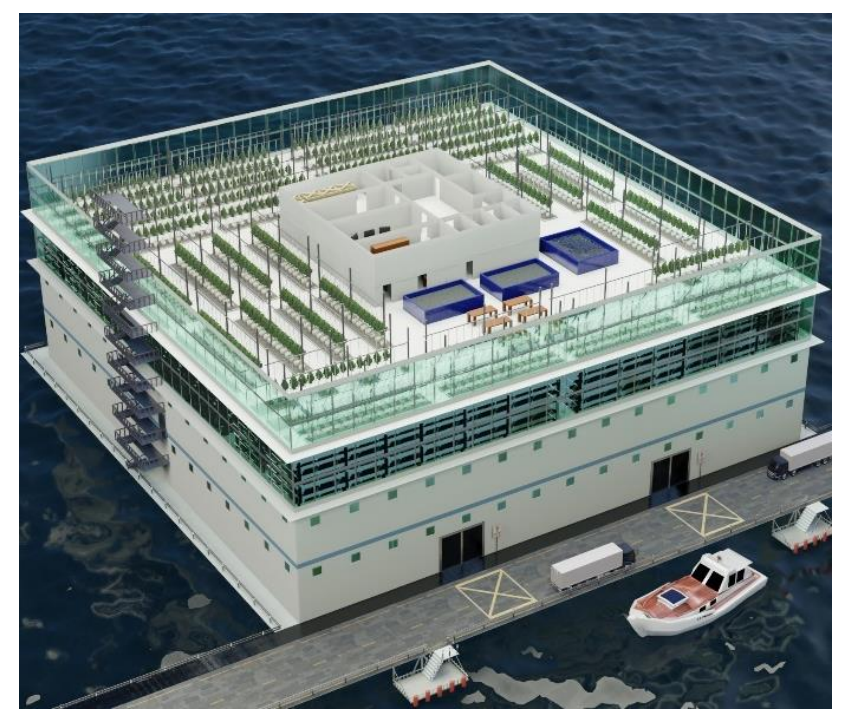

(b)

Figure 16. Arrangement of Level \#4\&5: a) Plan and b) 3D sectional view

Table 10. Indoor Tomato production of Level \#4

\begin{tabular}{|l|l|l|}
\hline Total production area footprint $(0.8)$ & 2560 & $\mathrm{~m} 2$ \\
\hline Number of layers/tiers per rack & 2 & \\
\hline Total production/growing area & 5120 & $\mathrm{~m} 2$ \\
\hline Plant per m2 & 3 & $\mathrm{plant} / \mathrm{m} 2$ \\
\hline Total Plants & 15360 & $\mathrm{plant}$ \\
\hline Harvest cycle & 312 & $\mathrm{days}$ \\
\hline Harvest per m2 & 63.00 & $\mathrm{~kg} / \mathrm{m} 2 / \mathrm{year}$ \\
\hline Annual harvest & 322,560 & $\mathrm{~kg} / \mathrm{year}$ \\
\hline Annual Inedible mass & 225,792 & $\mathrm{~kg} / \mathrm{year}$ \\
\hline Annual Nutrients solution & $1,675,159$ & $\mathrm{~kg} /$ year \\
\hline Annual power consumption & $5,210,847$ & $\mathrm{kWh} / \mathrm{year}$ \\
\hline Annual water circulation & 18,637 & $\mathrm{~m} 3 /$ year \\
\hline
\end{tabular}

Following Table 11, the break-even price obtained for cherry tomatoes is $\$ 4.5 / \mathrm{kg}$, whereas the current retail price in Singapore is around $\$ 7.5-19 / \mathrm{kg}$. [32]

Table 11. CAPEX for Tomato indoor Level \#4

\begin{tabular}{|l|l|}
\hline Horticulture eq- $\mathrm{t}$ & $\$ 164,567$ \\
\hline Hydroponic system & $\$ 389,688$ \\
\hline Illumination eq- $\mathrm{t}$ & $\$ 2,898,884$ \\
\hline Environment/ Health Control eq- $\mathrm{t}$ & $\$ 62,413$ \\
\hline
\end{tabular}




\begin{tabular}{|l|l|}
\hline HVAC system & $\$ 714,735$ \\
\hline Core/process/packing eq-t & $\$ 25,600$ \\
\hline Total CAPEX & $\mathbf{\$ 4 , 2 5 5 , 8 8 6}$ \\
\hline
\end{tabular}

\subsubsection{Level \#5 High wire tomato Green House}

Level\#5 is designed as a Green House, additionally equipped with a glassy/transparent roof. It provides greater sunlight; therefore, it is best suitable for growing plants. In this project, the same vertical high wire vine crop system is selected as per Level \#4 (Figure 17). The only difference is that power consumption is reduced by 3 times, and the cost of electrical equipment is reduced by 2 times (estimated) due to the high level of sunlight. Therefore, following the same prototype [31], the production details remain the same as in Table 10, with the annual power consumption reduced to $1,736,949 \mathrm{KWh}$ for Level\#5. The CAPEX, in this case, is reduced to $\$ 2,806,444$ as compared to Table 11. The price for cherry tomato for this farm is assumed $\$ 4.5 / \mathrm{kg}$, the same as for the previous (Level\#4) farm.

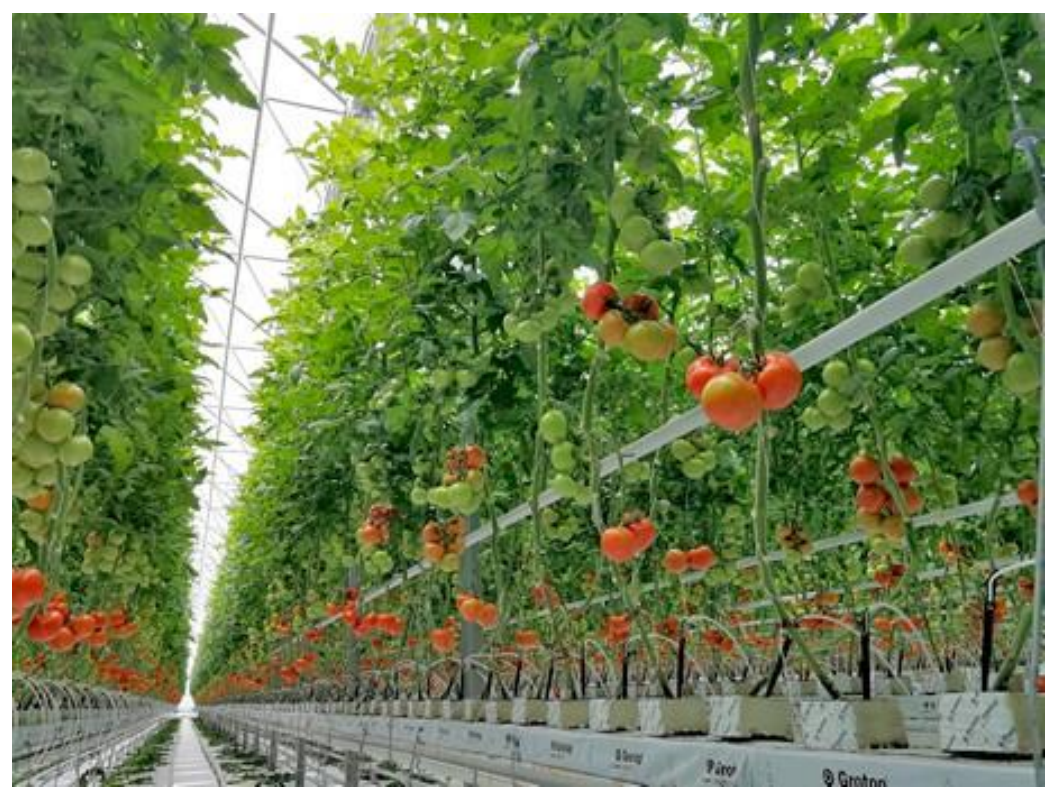

Figure 17. Example of High wire tomato [33]

\subsection{Estimated Capital Cost for the MFF}

A summary of the total capital cost for the entire multi-level floating farm is presented in Table 12, combining the estimated costs described across various subsections of section 3.3 above.

Table 12. CAPEX summary

\begin{tabular}{|l|l|l|}
\hline Table 1 & Floater and Basic Equipment & $\$ 31,456,805$ \\
\hline Table 3 & Fish Farm & $\$ 7,786,139$ \\
\hline Table 5 & Mushroom Farm & $\$ 35,349$ \\
\hline
\end{tabular}




\begin{tabular}{|l|l|l|} 
Table 7 & Egg Production Farm & $\$ 3,100,000$ \\
\hline Table 9 & Leafy Greens Farm & $\$ 8,319,115$ \\
\hline Table 11 & Tomato indoor Farm & $\$ 4,255,886$ \\
\hline No table & Tomato Greenhouse & $\$ 2,808,444$ \\
\hline & Total CAPEX & $\mathbf{5 7 , 7 6 1 , 7 3 8}$ \\
\hline
\end{tabular}

\subsection{Hydrostatics and Stability}

To prevent the MFF from capsizing, investigations with both intact and damage stability are required. Criteria for stability must be complied with and approved by the Maritime Authorities. The basic hydrostatics for the proposed MFF, considering the total displacement of 25830 tones at the draft $7 \mathrm{~m}$ (Figure 18), is presented in Table 13.

Table 13. Hydrostatic characteristics

\begin{tabular}{|l|l|l|l|l|l|}
\hline Parameter & Value & Unit & Parameter & Value & Unit \\
\hline Length & 60 & $\mathrm{~m}$ & Max sectional area & 420 & $\mathrm{~m}^{\wedge} 2$ \\
\hline Beam & 60 & $\mathrm{~m}$ & Waterplane Area & 3600 & $\mathrm{~m}^{\wedge} 2$ \\
\hline Draft Amidships & 7 & $\mathrm{~m}$ & KB & 3.5 & $\mathrm{~m}$ \\
\hline Main Deck freeboard & 2 & $\mathrm{~m}$ & KG & 20 & $\mathrm{~m}$ \\
\hline Depth & 9 & $\mathrm{~m}$ & BMt /BML & 42.9 & $\mathrm{~m}$ \\
\hline Height & 39 & $\mathrm{~m}$ & GMt / GML uncorrected & 26.4 & $\mathrm{~m}$ \\
\hline Displacement & 25830 & $\mathrm{t}$ & KMt/ KML & 46.4 & $\mathrm{~m}$ \\
\hline Volume (displaced) & 25200 & $\mathrm{~m}^{\wedge} 3$ & Immersion (TPc) & 36.9 & ton/cm \\
\hline Wetted Area & 5280 & $\mathrm{~m}^{\wedge} 2$ & MTc & 113.5 & ton.m \\
\hline
\end{tabular}

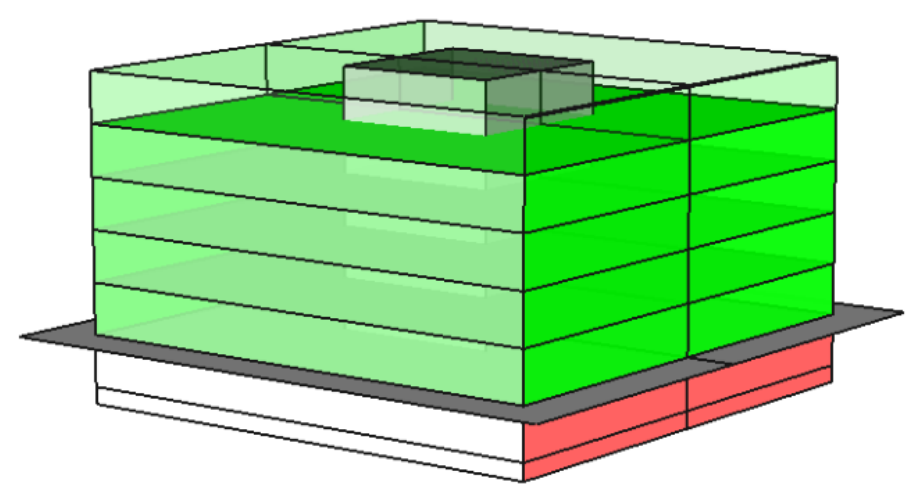

Figure 18. Hydrostatic model of MFF

As can be seen, the Metacenter KM is quite high $(=46.4 \mathrm{~m})$, which is a clear indication of a large initial stability margin, even if considering most conservative Free Surface Corrections ( ignored 
at this stage) and most conservative $\mathrm{KG}=20 \mathrm{~m}$. This allows the addition of more floors without too much concern for stability. However, the impact of wind force should be included in this estimation to get dynamic stability behavior. Also, to improve the damage stability, the pontoon/ Level \#0 is subdivided into several watertight compartments by arranging WT double bottom and bulkheads.

\subsection{Mooring}

Floating structures like floating farms require to be moored at the selected locations for a longer duration. The following main categories of mooring options were briefly considered for this project:

- $\quad$ Spread Mooring

- Anchoring

- Piling

- Turret

- Dynamic Positioning

- Suction pile/anchor with tension legs

The decision on the selection of a proper mooring system depends on Metocean conditions, type of structure, duration of operation, water depth, environmental considerations, seabed properties (bathymetry, soil characteristics), etc. For example, for this project:

- Spread mooring is not a good option for nearshore and low depth operation due to its larger footprints.

- Anchoring is not a good solution for longer-term mooring.

- Turret mooring is not a feasible choice for the type of rectangular large floating structure considered in this study.

- Dynamic positioning will not be economically viable, as well as technically feasible for such a shallow depth.

- Similarly, suction/tension leg mooring is not a good option for shallow water applications.

Hence, piling appears to be the most suitable mooring choice for the proposed project.

\subsection{Motions}

The piles will only fix the horizontal translation of the MMF, and it is free to move up and down (heave), also has some freedom in roll or pitch motions. However, these motions and accelerations will require to be within allowable limits to ensure the comfort of the people onboard, also for the poultry production. Though, in sheltered Singapore water, this will not be a big concern. 


\section{OPERATION AND MAINTENANCE CHALLENGES}

\subsection{Power Generation}

A major component of the farm infrastructure is the supply of energy. The electricity demand for the entire MMF is estimated as 22,212,000 kWh/year (significantly influenced by the hydroponic farms). Various methods of electric power supply and cost per kWh are evaluated and compared in the following subsections.

\subsubsection{Shore power supply}

Shore supply requires building a substation of acceptable standards and cables to provide onboard power to a distribution center. The resultant cost involves a project investment and the electricity tariff, comprise of an energy charge $(\mathrm{kWh})$ and a demand charge $(\mathrm{kVA})$. Considering the current electricity tariffs of $0.23-0.25 \mathrm{SG} \$ / \mathrm{kWh}$ in Singapore [34], the combined costs make this alternative impractical for growing cheap vegetables.

\subsubsection{Onboard power generation- conventional diesel}

Considering a conventional diesel-driven generator plant, the cost for unit electricity, including $2 \times 1600 \mathrm{kVA}$ generating units with appropriate switchgear $(2 \mathrm{x} 50 \%$ units would be better for redundancy and reliability than $1 \times 100 \%$ ) is shown in Table 14 . The fuel required by a conventional diesel generator is $300 \mathrm{l} / \mathrm{hr}$., at the cost of $\$ 0.62 / 1$ [35]- (conservatively estimated considering historical fluctuations).

Table 14. Electricity cost from diesel fuel

\begin{tabular}{|l|l|l|}
\hline Annual energy requirement & $22,212,049$ & kWh. \\
\hline Generator capacity 2X1600kVA & 3,200 & kVA \\
\hline Est. cost of Power Generation (PG) group & $\$ 2,000,000.00$ & SGD \\
\hline Fuel Consumption 1x1600 at $80 \%$ & 300 & L/hrs. \\
\hline Annual Fuel req-t & $4,164,759$ & L/year \\
\hline Price of 1L diesel & $\$ 0.62$ & SGD \\
\hline Total cost of fuel, annual & $\$ 2,579,939.31$ & SGD \\
\hline Labour 2 man $12 / 7$ each* $\$ 2500$ & $\$ 60,000.00$ & SGD \\
\hline Maintenance $0.3 \%$ & $\$ 6,000.00$ & SGD \\
\hline Total & $\$ 2,645,939.31$ & SGD \\
\hline Cost of electricity & $\mathbf{\$ 0 . 1 2}$ & SGD \\
\hline
\end{tabular}

\subsubsection{Onboard power generation- LNG LP multifuel diesel}

This per unit electricity cost calculation for this alternative is summarized in Table 15, which is subjected to the following assumptions: 
- Heat content of diesel oil is 138,000 BTU/Gal and the estimated cost of LP LNG engine 1.7 times the cost a conventional engine [36], rounded up to $\$ 3,400,000$.

- The price of LNG fuel: Henry Hub (31.05.2020) \$2.56 + Liquefaction (assumed) \$5.60+ Distribution (assumed) $\$ 3.50=\$ 11.66 \mathrm{SGD} / \mathrm{mmBTU}$. [37]

Table 15. Electricity cost from LNG fuel

\begin{tabular}{|l|l|l|}
\hline Annual energy requirement & $22,212,049$ & $\mathrm{kWh}$. \\
\hline Generator capacity 2X1600kVA & 3,200 & $\mathrm{kVA}$ \\
\hline Total cost of PG group & $3,400,000$ & $\mathrm{SGD}$ \\
\hline Heat content of diesel oil & 138,000 & $\mathrm{BTU} / \mathrm{Gal}$ \\
\hline LNG Consumption 1x1600 at $80 \%$ & 79.8 & USGallon/hour \\
\hline & 11.019 & $\mathrm{MMBTU} / \mathrm{hour}$ \\
\hline Annual LNG req-t & $153,000 \mathrm{MMBTU}$ & $147,969 \mathrm{~m} 3$ \\
\hline Price LNG SGD /MMBTU & $\$ 11.70$ & SGD $/ \mathrm{MMBTU}$ \\
\hline Total cost of LNG, annual & $1,784,286$ & SGD/year \\
\hline Labour 2-man 12/7 each*\$2500 & 60,000 & SGD \\
\hline Maintenance 0.3\% & $\$ 10,200.00$ & SGD \\
\hline Total Operating Cost & $\$ 1,854,486.00$ & SGD \\
\hline Energy cost & $\mathbf{\$ 0 . 0 8}$ & SGD \\
\hline
\end{tabular}

\subsubsection{Onboard power generation- Gas turbine generator}

Another available option is gas turbine generators, which is one of the most widely used power generating technologies. However, it is most efficient at maximum power output, and its efficiency declines steadily as the output power reduces. The preliminary analysis also indicated that the cost of energy is high and not suitable for the present system.

\subsubsection{Summary}

A comparative analysis of various alternatives is presented in Table 16.

Table 16. Alternative fuel for Power generation

\begin{tabular}{|l|l|l|l|l|}
\hline Alternative & Fuel & Storage & $\begin{array}{l}\text { Est. } \\
\text { (SGD) } \\
\text { kWh }\end{array}$ & $\begin{array}{l}\text { Cost } \\
\text { per }\end{array}$ \\
Y/N \\
\hline Diesel & Diesel & Bunker delivery and tank storage & 0.12 & $\mathrm{Y}$ \\
\hline Diesel LNG & LNG & $\begin{array}{l}\text { Bunker delivery and ISO tank } \\
\text { storage }\end{array}$ & 0.08 & $\mathrm{Y}$ \\
\hline Diesel -Gas & Pipeline & Not available & N/A & $\mathrm{N}$ \\
\hline Gas Turbine & LNG & Bunker delivery and ISO tank & 0.212 & $\mathrm{~N}$ \\
\hline
\end{tabular}




\begin{tabular}{|l|l|l|l|l|}
\hline Shore Gas Supply & n/a & Not Available N/A & N \\
\hline Solar Supply & n/a & Insufficient capability & 0.035 & Y \\
\hline Shore Power Supply & n/a & $\begin{array}{l}\text { Requires own substation and not } \\
\text { available }\end{array}$ & Y \\
\hline
\end{tabular}

As can be seen, the most cost-effective approach at this time is to endorse a Power Generation system consisting of two diesel generating units fueled by dual fuel (diesel and/or LNG). The fuel selected is LNG regasified as this is the cleanest and cheapest option offering the following benefits:

- Lower energy cost per ton because of high energy density (nearly $24 \%$ compared to Heavy Fuel Oil (MGO-HFO))- LNG provides 50GJ/ton of energy, whereas HFO only provides $40.5 \mathrm{GJ} /$ ton [36].

- The ability to burn a variety of fuels and immediately switch fuels during operation without reducing load or sacrificing power plant availability. Thus, offering fuel security and flexibility.

- Reduction in Sulphur oxide (SOx) emissions by 90-95\%, and carbon dioxide (CO2) emissions by $20-25 \%$ [36]

However, regardless of the fuel used, it is imperative that the environmental impacts of discharged gases, noise and vibration are considered. Selective Catalytic Reduction (SCR) units will be fixed to the exhaust stacks inside the engine rooms to reduce NOx. These generators will be enclosed in a sound-absorbing enclosure with vibration dampers of sufficient size to eliminate vibration transferred to the ocean floor. The main switchboard will be of 415 Volts at $50 \mathrm{~Hz}$ with all bus bars and the power system sized to accommodate the short circuit level of the main power supply.

\subsection{Fresh Water Supply}

In the MFF, various cultivation systems require a different amount of freshwater supply, for example:

- The amount of water need for grown fish is $0.86 \mathrm{~m}^{3} / \mathrm{kg}$ [23], which results in a freshwater requirement of 420,000-550,000 $\mathrm{m}^{3} /$ year for freshwater fish [23] (assuming $10-15 \%$ of refreshing water per day). RAS will allow a significant reduction of freshwater demand, but a conservative estimation is taken. For seawater fish, the total demand for freshwater is estimated as 4,000-5,000 $\mathrm{m}^{3} /$ year (mostly processing and technical needs).

- For the poultry farm, the annual demand for freshwater for 23,000 birds is estimated at $8,500 \mathrm{~m}^{3} /$ year [38].

- For a vertical hydroponic farm with artificial lights (e.g. leafy greens-lettuce), the estimated water need is $12,000-13,000 \mathrm{~m}^{3} /$ year. ( Calculated based on the transpiration rate of $31 / \mathrm{m}^{2}$ per day for the mature crop (lettuce) [31]. 
- For indoor high wire tomato, the transpiration rate is $41 / \mathrm{m}^{2}$ per day [31]. Thus, the total volume of top-up water is estimated at $5,000-7,000 \mathrm{~m}^{3} /$ year.

- For other needs, $9 \mathrm{~m}^{3} /$ day $\left(\sim 3500 \mathrm{~m}^{3} /\right.$ year $)$ is assumed.

Therefore, the total annual project demand for freshwater will be 40,000-50,000 $\mathrm{m}^{3}$ (assuming seawater fish cultivation) or up to $600,000 \mathrm{~m}^{3}$ (for freshwater fish cultivation). However, a significant part of it could be re-circulated. Various approaches to satisfying these water demands are discussed in the following subsections.

\subsubsection{Replenishing water tanks from shore}

The price of freshwater supply in Singapore for household use varies from $2.74 \mathrm{SG} \$ / \mathrm{m} 3$ to 3.69 $\mathrm{SG} \$ / \mathrm{m} 3$, and the costs of industrial water supply are [39]:

- NEWater price $2.33 \mathrm{SG} \$ / \mathrm{m}^{3}$;

- Industrial water price $1.58 \mathrm{SG} \$ / \mathrm{m}^{3}$;

- Potable water price for shipping customers $3.80 \mathrm{SG} \$ / \mathrm{m}^{3}$

If considering the cheapest option, Industrial water, the estimated water cost for the entire MMF will be $\$ 75,800$ (if seawater fish is cultivated) or $\$ 950,000$ otherwise (freshwater fish cultivation).

\subsubsection{Onboard freshwater generation options}

Distillation is the process of producing fresh water from seawater by evaporating and recondensing it. A modern low-temperature Vacuum Vapor Compression (VVC) desalination unit can operate at $40^{\circ} \mathrm{C}$ to $45^{\circ} \mathrm{C}$. Distillation is cheaper and more efficient for relatively small consumers.

Reverse Osmosis (RO) works by forcing water through a semi-permeable membrane, using osmotic pressure. It strips the water of heavy metals, salts, bacteria, and total dissolved solids (TDS) and provides water of remarkable purity. However, reverse-osmosis faces inherent economic and technical limitations:

- It is an energy-intensive process (typically $3.4-4.8 \mathrm{kWh} / \mathrm{m} 3$ with an energy recovery unit and up to $9 \mathrm{kWh} / \mathrm{m}^{3}$ without energy recovery [40]) due to very high feed pressure (800 to 1000 psi) requirements.

- Operating costs are also quite high, ranging from 2-5 times higher than the Multi-Effect Plate (MEP) evaporator systems [40].

Thus, Reverse osmosis is normally used where large quantities of water is consumed.

Electrodialysis (ED) process is a relatively new method based on an electrochemical separation process that selectively removes salt ions based on their electrical charge by transferring them through semi-permeable ion exchange membranes charged with a direct current voltage. The 
electrodialysis process has been demonstrated to be much more energy-efficient, using just 1.8 $\mathrm{kWh} / \mathrm{m} 3$, half the energy required for reverse-osmosis.

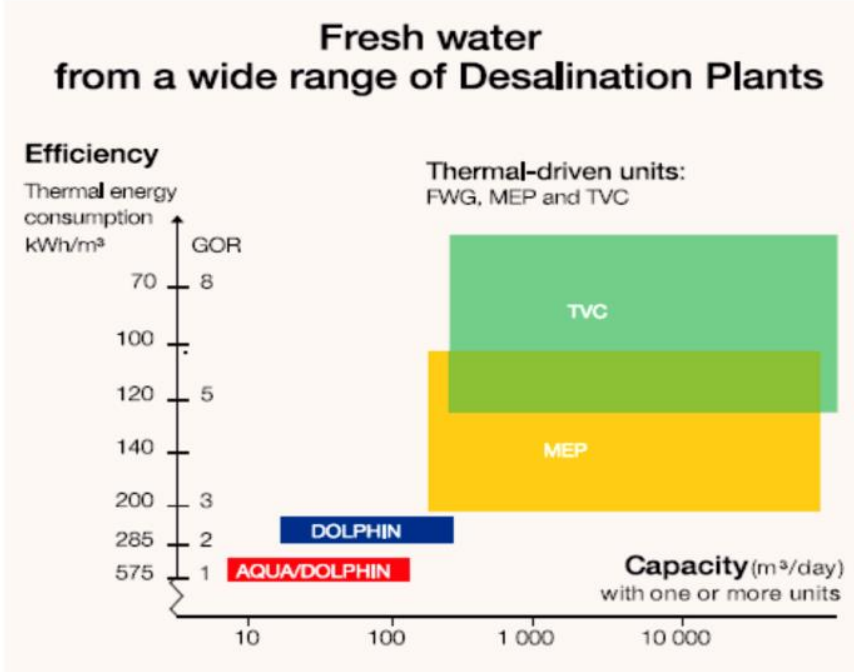

GOR (Gain Operation Value) expresses the ratio of produced quantity of distillate to steam consumption

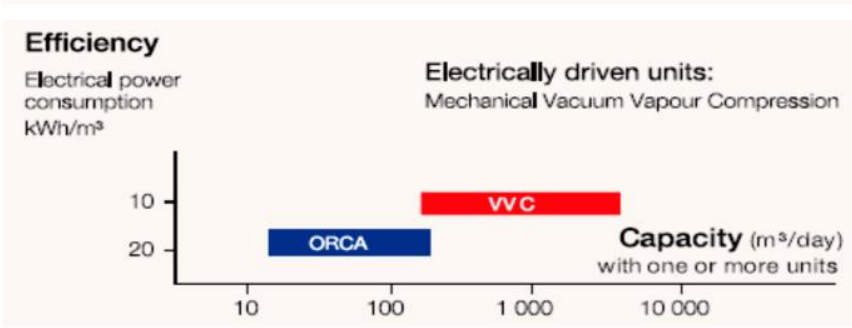

Figure 19. Freshwater generation efficiency [40]

The estimated power requirement for Freshwater $(\mathrm{FW})$ production will be between $72,000 \mathrm{kWh}$ and 2,700,000kWh per year (depends on the type of FW generation and FW demand for fish farm) (Figure 19). The cost per $\mathrm{m}^{3}$ shall also include chemicals/consumables, spare parts, and water quality requirements. In general, the generation of FW onboard is more economically efficient than purchasing from third parties but requires high initial investments.

However, all FW generators have limited capability when used in port or estuarial waters, owing to the contamination by dissolved metals (mercury predominantly), sewage, sand/sediments from reclamations in the water [41]. Special countermeasures (for example, a pre-filtration) are required if generators have to be used in contaminated areas [42]. 


\subsection{Ventilation and air-conditioning}

As mentioned in section 2, each level of MFF (21600m3) is separated into two zones: Production zone $(19200 \mathrm{~m} 3)$ and Core area $(2400 \mathrm{~m} 3)$ for offices, stores, machinery room, nursery, etc. The Production zones may require cooling if plants/livestock need a specific environment different from typical Singapore climates or when heat dissipation from lights/equipment will be too high. For example, the comfortable temperature for egg-laying chickens is $24-26^{\circ} \mathrm{C}$ - production will be reduced if the temperature exceeds this range.

Some farms may also require special measures to avoid cross-contamination of air, such as poultry and/or mushroom farms. Special airlocks/filters (PP 6.6) have to be installed in such cases to ensure Production areas of each floor have independently regulated (or maybe entirely separated) ventilation system. Local ducting distribution for Production areas on each floor shall be installed/adjusted after the installation of all farming equipment. A redundancy of $50 \%$ is assumed.

A dedicated air conditioning system with independent control should be provided for all Core areas to satisfy human comfort and temperature-sensitive equipment. However, lower Core areas could have some rooms (including processing and nurseries) that will be connected to Production zone ventilation only. Estimations of power consumption for the HVAC system are included in each farm's total power consumption and already shown in section 4 .

\subsection{Mode of operations: build-to-order vs build-to-rent}

From the point of view of MFF's owner, two modes of operation are considered in this project: Build-to-order and Build-to-rent.

It should be noted that the resulting profit and loss analysis presented here are preliminary estimations of the profitability of the facility. The balance sheet, reflecting the total Assets vs Liabilities and the way how the project shall be funded, is not presented here, as the purpose is only to demonstrate the capability of the facility in generating reasonable income.

\subsubsection{Build-to-order mode}

Build-to-order is when an investor orders construction of MFF for own use. It is the more expensive mode which requires a higher level of initial investment, but has its advantages:

- All CAPEX for farms and for floater will be considered together, which leads to increased depreciation.

- Selections of farms and developed cultures could be planned, keeping in mind the most efficient integration, which allows the owner to get extra profit.

- Integration and cooperation could be incorporated into the initial design, including equipment and space for processing, storage and delivery. By-products will be processed, circulated between different farms and used free of charge. 
- In the case of independent-from-shore supply, the fees for power and water supply will not be considered in OPEX. Instead, there will be additional costs for fuel and consumables, spare parts, and marine equipment maintenance required for its production.

- Management, marketing and office labor could be shared between all farms- which saves money.

- The owner will bear all risks but also get all benefits and extra profit from the fluctuation of the food market.

These together will provide a higher annual income (Table 17) compared with rent-out mode (Table 18).

Table 17. Overall cost \& profit estimation of Build-to-order mode

\begin{tabular}{|c|c|}
\hline & Value in SGD \\
\hline Capital Expenditure (Floater + Farms) & $\mathbf{5 7 , 7 5 9 , 7 3 8}$ \\
\hline \multicolumn{2}{|l|}{ Sales Revenue (assuming 25-30\% markup) } \\
\hline \#0 Fish farm & $\$ 4,044,785$ \\
\hline \#1 Mushroom Farm & $\$ 877,688$ \\
\hline \#2 Egg Farm & $\$ 4,782,059$ \\
\hline \#3 Lettuce Farm & $\$ 4,649,509$ \\
\hline \#4 Tomato Farm & $\$ 2,370,816$ \\
\hline \#5 Tomato Farm & $\$ 2,370,816$ \\
\hline Total Sales Revenue $[\mathrm{J}]$ & $\$ 19,095,672$ \\
\hline \multicolumn{2}{|l|}{ Cost of Sales } \\
\hline Fuel (LNG) & $\$ 1,784,286$ \\
\hline Water & $\$ 0$ \\
\hline Provision & $\$ 112,600$ \\
\hline Consumables & $\$ 88,200$ \\
\hline CoS from Farming & $\$ 7,108,138$ \\
\hline Total Cost of Sales [K] & $\$ 9,093,224$ \\
\hline Gross Profit $[\mathrm{L}=\mathrm{J}-\mathrm{K}]$ & $\$ 10,002,448$ \\
\hline \multicolumn{2}{|l|}{ Operating Expenses } \\
\hline \multicolumn{2}{|l|}{ Sales, Marketing and Administrative } \\
\hline Advertising & $\$ 70,000$ \\
\hline Wages and salaries & $\$ 986,597$ \\
\hline Repairs and maintenance & $\$ 180,000$ \\
\hline Total Sales, Marketing and Administrative [M] & $\$ 1,236,597$ \\
\hline \multicolumn{2}{|l|}{ Research and Development } \\
\hline Technology licenses, fees & $\$ 50,000$ \\
\hline Total Research and Development Expenses [N] & $\$ 50,000$ \\
\hline Total Operating Expenses [P=M+N] & $\$ 1,286,597$ \\
\hline
\end{tabular}




\begin{tabular}{|c|c|}
\hline $\begin{array}{l}\text { EBITDA (earnings before interest, taxes, } \\
\text { depreciation, and amortization) }[\mathrm{Q}=\mathrm{L}-\mathrm{P}]\end{array}$ & $\$ 8,715,851$ \\
\hline \multicolumn{2}{|l|}{ General Expenses } \\
\hline Depreciation 20 years & $2,887,987$ \\
\hline Insurance $2.5 \%$ & $1,443,993$ \\
\hline Interest $3.0 \%$ & 736,437 \\
\hline Total General Expenses [O] & $5,068,417$ \\
\hline Total Operating Expenses $[\mathrm{P}=\mathrm{M}+\mathrm{N}+\mathrm{O}]$ & $6,355,014$ \\
\hline Income from Operations [Q=L-P] & $3,647,434$ \\
\hline \multicolumn{2}{|l|}{ Taxes } \\
\hline Income taxes $17 \%$ & 620,064 \\
\hline Total Taxes [S] & 620,064 \\
\hline Net Profit $[\mathrm{T}=\mathrm{Q}-\mathrm{S}]$ & $3,027,371$ \\
\hline
\end{tabular}

\subsubsection{Build-to-rent mode}

The build-to-rent mode is when an investor/owner will build a floater speculatively, without intentions to produce food, but rather to rent out space for such development. The Production areas of each level will be left empty (without any farming equipment, fittings, etc.) and will be leased to farmers who will set up their farms with all internals as required. Key features will be:

- Renter will provide an empty warehouse with all communications delivered to the floor. The suggested area for rent include Production areas and 2 levels of Core zones.

- The tenants will rent an empty warehouse and shall build/install all required equipment and bear all initial investments for their own farm. The tenant will also be fully responsible for the operations and maintenance of the farm.

- The tenant will sell its own products, bear all risks, but will also get all additional profits/income from favorable market fluctuation.

- Management, marketing and office labor shall be borne by each tenant individually.

- Integration between farms in MFF still will be possible but will require good relations between neighbors and additional expenses- mostly for by-product/waste management (PP 6.4). By-products will be sold between participants and become an additional source of income for each tenant.

- Costs and benefits for each tenant are calculated from break-even prices, but not provided here as irrelevant for the discussion.

- Renter will get fixed income, paid by tenants (Table 18): rent fee per square meter, electricity bills per kWh, water supply bills per $\mathrm{m} 3$, ventilation supply per $\mathrm{m} 3$, etc.

- Rental statistics for Singapore industrial warehouses are within 7.5 43 SG\$/m2 [43], so a statistically average of $11 \mathrm{SG} \$ / \mathrm{m} 2$ per month was assumed for calculation. Some areas can be rented with higher fees due to various valueadded features, e.g. top level with Green House due to its sunlight irradiation 
and bottom level with unique features suitable for fish/crustacean/seaweed cultivation.

- For freshwater, the lowest water price in Singapore of $1.7 \$ / \mathrm{m} 3$ was assumed for seawater fish cultivation.

- For electricity, the lowest price in Singapore of $\$ 0.15 / \mathrm{kWh}$ is used.

- Sales of air conditioning services are estimated at $\$ 493,000$ per year.

- All utility prices, as estimated, shall be attractive for tenants.

Therefore, as can be seen, this mode provides a lower risk of investment and sequent lower-income (Table 18).

Table 18. Overall cost \& profit estimation of Build-to-rent mode

\begin{tabular}{|l|l|}
\hline & Value in SGD \\
\hline Capital Expenditure (Floater only) & $\mathbf{3 1 , 4 5 6 , 8 0 5}$ SG\$ \\
\hline Sales Revenue (from Tenants) & \\
\hline Rental fees & \\
\hline Sales of electricity & $\$ 3,005,800$ \\
\hline Sales of freshwaters (seawater fish) & $\$ 3,331,808$ \\
\hline Sales of aircon/ventilations & $\$ 82,562$ \\
\hline & $\$ 493,000$ \\
\hline & \\
\hline Total Sales Revenue [J] & \\
\hline & $\mathbf{\$ 6 , 9 1 3 , 1 6 9}$ \\
\hline Cost of Sales & \\
\hline Fuel (LNG) & \\
\hline Water & $\mathbf{\$ 1 , 7 8 4 , 2 8 6}$ \\
\hline Provision & $\mathbf{\$ 0}$ \\
\hline Consumables & $\mathbf{\$ 1 1 2 , 6 0 0}$ \\
\hline & $\mathbf{\$ 8 8 , 2 0 0}$ \\
\hline Total Cost of Sales [K] & \\
\hline & $\mathbf{\$ 1 , 9 8 5 , 0 8 6}$ \\
\hline Gross Profit [L=J-K] & \\
\hline & $\mathbf{\$ 4 , 9 2 8 , 0 8 3}$ \\
\hline Operating Expenses & \\
\hline Sales, Marketing and Administrative & \\
\hline Advertising \& marketing & $\mathbf{\$ 5 0 , 0 0 0}$ \\
\hline Wages and salaries & $\mathbf{\$ 5 0 0 , 0 0 0}$ \\
\hline Repairs and maintenance & $\mathbf{\$ 1 1 1 , 0 0 0}$ \\
\hline Total Sales, Marketing and Administrative [M] & $\mathbf{\$ 6 6 1 , 0 0 0}$ \\
\hline & \\
\hline Research and Development & $\mathbf{\$ 5 0 , 0 0 0}$ \\
\hline Technology licenses, fees & $\$ 50,000$ \\
\hline Total Research and Development Expenses [N] \\
\hline
\end{tabular}




\begin{tabular}{|l|l|}
\hline & \\
\hline Total Operating Expenses [P=M+N] & $\$ 711,000$ \\
\hline $\begin{array}{l}\text { EBITDA (earnings before interest, taxes, } \\
\text { depreciation, and amortization) [Q=L-P] }\end{array}$ & $\mathbf{\$ 4 , 2 1 7 , 0 8 3}$ \\
\hline General Expenses & \\
\hline Depreciation 20 years & $1,572,840$ \\
\hline Insurance 2.5\% & 786,420 \\
\hline Interest 3.0\% & 401,074 \\
\hline Total General Expenses [O] & $2,760,335$ \\
\hline & \\
\hline Total Operating Expenses [P=M+N+O] & $3,471,335$ \\
\hline & \\
\hline Income from Operations [Q=L-P] & $\mathbf{1 , 4 5 6 , 7 4 9}$ \\
\hline Taxes & \\
\hline Income taxes 17\% & 247,647 \\
\hline Total Taxes [S] & 247,647 \\
\hline & \\
\hline Net Profit [T=Q-S] & $\mathbf{1 , 2 0 9 , 1 0 2}$ \\
\hline
\end{tabular}

\section{IMPROVING THE EFFICIENCY AND SUSTAINABILITY}

The preservation of the environment and fighting climate change is of global concern these days. Therefore, following the UN Sustainable Development Goals (SDGs), significant attention was given to ensure the efficient and sustainable operation of the MFF model presented here.

\subsection{Adding extra farming levels to improve the economical operation}

The proposed floater has a displacement of 25,830 tons while floating at a draft of $7 \mathrm{~m}$. Considering the modular design, the addition of one extra level will increase total displacement (including the weight of extra level plus increasing of size and weight of pontoon with systems) by 4350 tons approximately. The estimated increase of CAPEX due to such weight increase is $\$ 4,750 \mathrm{~K}$, which will affect depreciation cost (it will make an additional $\sim 280 \mathrm{~K}$ SGD/year). At the same time, each additional level will generate an annual net profit of $\$ 450 \mathrm{~K}$ to $\$ 700 \mathrm{~K}$ (already including CAPEX and OPEX for farming), thus, leaving a considerable profit margin. It is important to note that the pontoon with utility machinery will cost 3-4 times more than each level without farming equipment, and all farms will evenly share this cost.

Vertical stacking of farms will reduce break-even prices, but the percentage drop for every subsequently added floor will also reduce (Figure 20). Therefore, comprehensive market analysis should be conducted to determine the most optimized combination of cultivation products. 


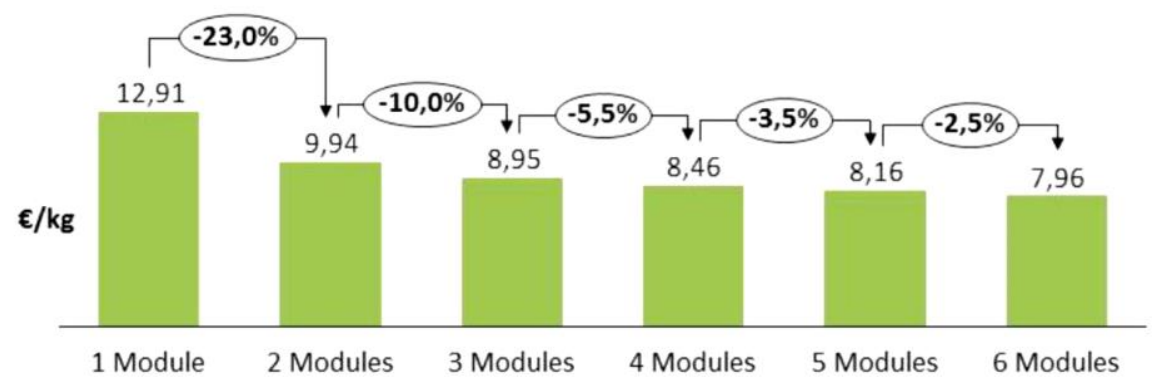

Figure 20. Typical reducing of break-even price per $\mathrm{kg}$ of product with the addition of one extra level/module [31]

The benefit of adding up extra farming floors is twofold - increasing income and production of more foods without increasing the footprint at sea. Besides, extra floors (up to some extent) will not significantly impact the stability of the floater due to the big margin in initial stability (Section 4.5).

\subsection{Energy conservation}

\subsubsection{Extracting Solar Energy}

Assuming that half of the $3600 \mathrm{~m}^{2}$ roof area of the MFF (Figure ) will be used for solar panels with $20 \%$ efficiency, it will generate $568.8 \mathrm{~K} \mathrm{kWh}$ of electricity per year (considering average solar irradiation of $1,580 \mathrm{kWh} / \mathrm{m} 2 /$ year for Singapore [20]). The cost of solar panel setup will be $\$ 300 \mathrm{~K}$ (@150SG\$/m2), and assuming 15 years return period, the estimated price for electricity will be only $\$ 0.035 / \mathrm{KWh}$, which is cheaper than any other available source but could only support about $3-5 \%$ of the MFF's power demand.

\subsubsection{Positioning, shape and arrangement of the hydroponic farms}

The hydroponic levels have high exposure to the sun because of the use of transparent glass walls/roof and operable windows (Figure ). To maximize the solar radiation at Levels\#3\&4, and to ensure that the sun evenly penetrates each level both in the morning and evening throughout the year, the floater is designed square-in-plane and positioned at NE to SW (45-degree to true North) orientation (Figure 21). 


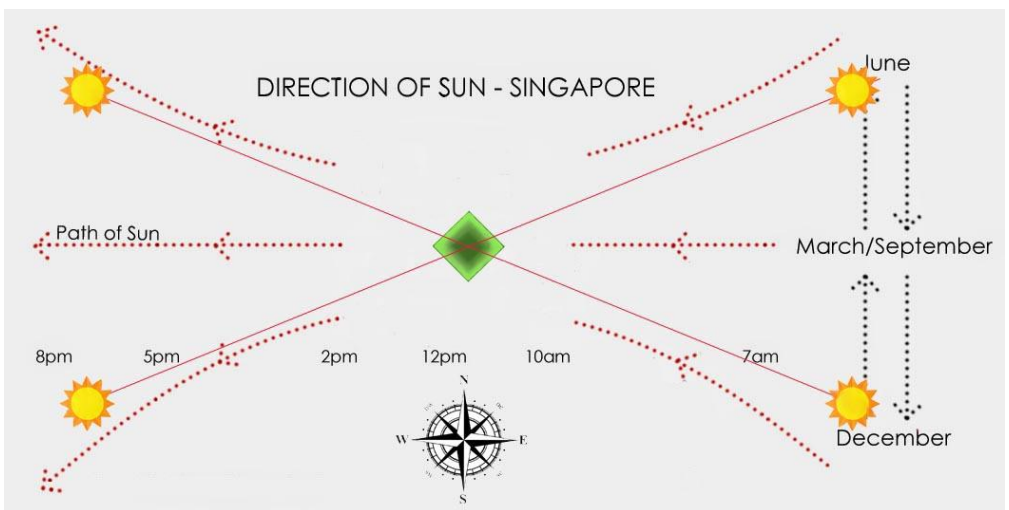

Figure 21. Annual trajectory envelop of the Sun over Singapore

All trays with plants on each farm are placed along the walls closer to windows, so that sun rays could penetrate in-between tiers/plants (Figure 22). Each row of plants is equipped with artificial lights and daylight sensors (lights will switch off upon the detection of solar radiation). The area near the center of each Level, where solar radiation is minimal, is arranged for other purposes (as explained earlier). This approach is estimated to reduce the electricity need for the hydroponic farm by $18-20 \%$.

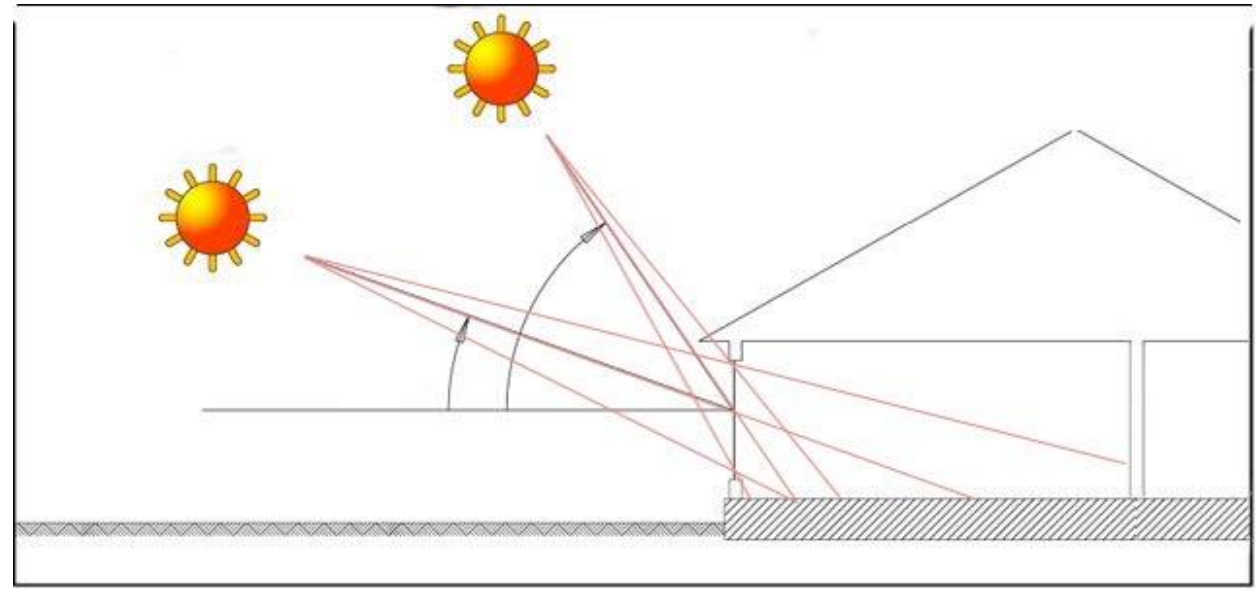

Figure 22. Daily trajectory of the sun

\subsubsection{Natural ventilation}

The temperature in Singapore could be as low as $20-24^{\circ} \mathrm{C}$, and there are a lot of windy days, especially during Monsoon seasons. Therefore, natural ventilation through operable windows will be availed as an effective and energy-efficient way to supplement HVAC systems (especially at sea) to provide outside air ventilation, cooling and thermal comfort. Automatic sensors will be used to stop the mechanical ventilation when windows are open, thereby reducing the costs and risk of the potential damage of equipment. 


\subsection{Water conservation}

\subsubsection{Collecting condensed air conditioning water.}

Air conditioning at each level of this MFF is estimated to produce up to $1320 \mathrm{~m}^{3}$ of water per year (considering water condensation from $33^{\circ} \mathrm{C} @ 100 \%$ humidity to comfortable temperature $23^{\circ} \mathrm{C} @ 80 \%$, and 8 circulation/day [20]), thus, a total of $7900 \mathrm{~m}^{3}$ annually for the entire facility. Besides, removing extra water evaporated from the plants in hydroponic, if needed, will increase this amount of condensed water even more. The water can be condensed using the existing HVAC system and then circulated back to FW system to support the demand.

\subsubsection{Harvesting rainwater}

On average, rainfall in Singapore is $2432 \mathrm{~mm} /$ year [20]. Therefore about $8,755 \mathrm{~m}^{3}$ of rainwater can be collected annually from the roof, which is nearly $20 \%$ of the entire FW demand (excluding fish farm). The maximum possible rainfall in Singapore is $1843 \mathrm{~m} 3$ per day. Therefore, a rainwater storage tank of 2000-2500 m3 is planned.

\subsection{Integrated waste management}

'Aquaculture can, in many circumstances, be combined with agriculture and animal husbandry with mutual advantage and contribute substantially to integrated development' [44]. Therefore, the proposed MFF provides the sustainable waste management opportunity by using the outputs/byproducts of one farming sub-system as inputs for another - so-called integration. Such integration requires an additional investment for processing those by-products. However, as discussed below, efficient planning makes it cost-effective and reduces the cost of nutrition/feeding.

\subsubsection{Poultry farm}

The use of poultry manure for feeding fish in the ponds is a century-old traditional technology and quite popular in many Asian countries. The pond ecosystem transforms the nutrients from manure to edible food for the fish [45]. However, suitable fish species must be chosen to make this integration work efficiently, such as silver carp, tilapia, milkfish as monocultures or in combination with shrimps, seaweeds and crabs (Table 19 ) [45]. Also, although poultry manure is rich in nitrogen, potassium and phosphorus, it should be noted that additional nutrition is still required to be added to fish feed [45].

Table 19. Typical Polyculture systems 


\begin{tabular}{ll|}
\hline $\begin{array}{l}\text { TFP indexes (Total Factor Productivity) by culture system. Based on } \mathbf{5 5} \text { farms. From Martinez- } \\
\text { Cordero et al. (1999) }\end{array}$ \\
\hline Culture System & Mean TFP \\
\hline Monoculture & 1,23 \\
\hline Polyculture with seaweed & 3,26 \\
\hline $\mathrm{G}+\mathrm{M}$ & 3,32 \\
\hline $\mathrm{G}+\mathrm{M}+\mathrm{S}$ & 4,42 \\
\hline $\mathrm{G}+\mathrm{M}+\mathrm{S}+\mathrm{C}$ & 2,49 \\
\hline Polyculture without seaweed & 1,39 \\
\hline $\mathrm{S}+\mathrm{M}$ & 1,28 \\
\hline $\mathrm{C}+\mathrm{M}$ & 3,57 \\
\hline $\mathrm{S}+\mathrm{C}$ & 1,13 \\
\hline $\mathrm{S}+\mathrm{C}+\mathrm{M}$ & 1,21 \\
\hline S=shrimp (Penaeus monodon), G=Seaweed (Gracilaria sp.), \\
M=Milkfish (Chanos chanos), C=Crab (Scylla serrata) \\
\hline
\end{tabular}

The poultry farm (about 60000 birds) in this project will produce 1,300 tons of manure annually [46], and the fish Farm could consume about 400-500 tons/year from it [44] [47]. The remaining amount can be processed and packed for selling in the retail market (the current market price is $\$ 4-8 / \mathrm{kg}$ ), thus, generating extra revenue.

\subsubsection{Fish farm}

A Reverse Osmosis water purification station could be used not only to desalinate sea waters, but also to process all wasted waters (widely used in Singapore [42]) from fish farms and redirect the processed waters to hydroponic farms. The benefit of this process is twofold: it eliminates discharge of wastes from fish farming and produces freshwater to support the MFF's demand at the same time. Considering the volume of proposed fish tanks and waters to be renewed several times over the years (depending on the fish species [44] [47]), the purification process will be able to significantly cover the water demands for the entire MFF.

\subsubsection{Agricultural farms}

In this project, the lettuce production will result in about 850 tons of inedible mass per year, and tomato production will add another 450 tons [31]. A significant portion of these fresh greens will be used to feed the poultry. Thus, reducing the cost of commercial feeds purchase [29] [47]. For the poultry farm, the annual feed demand is about 2,350 tons. Therefore, fresh and cheap greens from hydroponics will be a welcomed contribution to chicken feed. Besides, birds fed with vegetable-formulated feed exhibit higher rate of feed conversion expressed as muscle protein weight [48]. A portion of the hydroponic by-product could also be used as mushroom production media.

\subsubsection{Mushroom farm}

Mushrooms are perfect decomposers to utilize organic wastes, such as (hemi)cellulose, manure, lignin, leaves, and components of plants/greens [49]. On the other hand, spent mushroom substrate 
(SMS) is a waste product of mushroom cultivation, which could be utilized to ensure sustainable and efficient agricultural production. For example, SMS will be used as a compost to replace inorganic fertilizer partially. Mixed with other components, it will also be used as a growing medium for hydroponics. Several studies report the use of mushrooms or mushroom-extracts as fish/chicken feed and demonstrated that such diet resulted in a 1.2-1.7-fold higher growth rate. SMS can also be used as a feed source for insects, and insect protein can be used to feed fish and poultry [49] .

\subsection{Noise and vibration control}

The generation of high sound and vibration levels in water has the potential to change the behaviour of marine life and, in extreme cases, cause injury. It can also negatively affect the productivity of farming of fish and poultry/eggs [50]. No specific guidelines on noise and vibration control of floating farms have been found yet in the literature, although most of the existing codes of practice for ships can be adjusted and applied for such scenarios. Offshore classification societies such as DNV-GL have introduced Vibration Class (class notation VIBR) with guidelines on minimizing the risk of exceeding contractual vibration limits and reducing future maintenance and repair costs [51]. Another class notations, SILENT, provides criteria regarding underwater noise emission, reveals possible problem areas and estimates the amount of noise reduction to meet requirements, such as DNV GL Comfort Class, MSC 337(91), MLC, 2006, NORSOK, etc. [51] [52].

Apart from typical noise and vibration for ships, the proposed MFFs will have to deal with a few additional noise sources. Birds in cages, standard farming equipment, loading and unloading trucks - all will contribute to the noise inside the farms, which require installation of sound barriers, insulation, coatings, shock absorbers, seeking quieter alternatives for farming equipment (e.g. using coated chain feeders to reduce noise). [53].

\subsection{Emission of Harmful Gases from Farms}

The poultry and mushroom farms are known for reduced air quality with high concentrations of organic and inorganic dust, spores, pathogens and other micro-organisms as well as harmful gases such as ammonia, nitrous oxide, carbon dioxide, hydrogen supplied, and methane [54]. Specialized air cleaners should be installed to take care of these emissions, with plastic filters that are sprinkled with liquids to capture $\mathrm{NH}_{3}$, which could collect around $58 \%$ of the normally discharged emissions [50]. The treatment may use some type of impact curtains or biomass stack-wall as well. More recently, the use of wet scrubbers was investigated to precipitate dust, $\mathrm{NH}_{3}$ and odor from the exhausted air. Dietary manipulation is also reported as an effective means to lower ammonia emissions by reducing excessive nitrogen excretion or change of manure $\mathrm{pH}$ [55]. 


\section{CONCLUSION}

In this conceptual study, a 6-story MFF is introduced that can produce 9.5 million eggs, 450 tons of fish, 130 tons of mushrooms, 950 tons of leafy greens and 700 tons of tomato per year, with a substantial profit margin. A very conservative approach is used in this study to perform the cost estimations, which still reflect a substantial profit margin. Significant focus is also given on operational sustainability and efficiency. A few key points on operations are:

- Increasing the number of production floors will increase yield per $\mathrm{m}^{2}$, the overall productivity of MMF and reduce the cost of production.

- Smart use of sunlight and PV solar energy could reduce nearly 5-18\% of total energy demand.

- Collecting rainwater and condensate from the HVAC system ensure water conservation.

- The efficient integration of farms by reuse/recycle wastes will enhance economic benefits besides ensuring sustainability.

- Use of Reverse Osmosis on wasted waters from the fish farm will not only improve the quality of discharged water but also reduce the cost of FW water production.

- Use of dual-fuel/LNG engines for power generation will significantly reduce electricity cost compared to conventional sources. It will also reduce $\mathrm{CO}_{2}$ emission by $20-25 \%$, Sox emission by $90-95 \%$, and a significant reduction in NOx emission.

- Emission control to further reduce the release of harmful gases from farms.

- Control of noise and vibration for all equipment inside the MFFs will minimize the overall impact on the surrounding environment.

Floating farming is one of the most prominent ways to achieve domestic food security, especially for countries like Singapore, without much stress to urban development or the environment. The use of multi-level and multicultural farms requires high initial investments, at the same time will provide additional economic benefits- including maximum, sustainable food production, reduce of logistic expenses, shortening of delivery of fresh food to the actual point of consumption, localized control of quality as a value-added process. Thus, leading to positive geopolitical, environmental and economic consequences. 


\section{References}

[1] UN, "'World Population Prospects 2019: Highlights,"," NY, 2019.

[2] UN, "'How to Feed the World in 2050,"," United Nations, 2009.

[3] S. Fry, "The world's first floating farm making waves in Rotterdam," 16 Aug 2018. [Online]. Available: https://www.bbc.com/news/business-45130010. [Accessed 12 Sep 2020].

[4] WDCD challenge, "Floating Food Farm," [Online]. Available: https://challenge.whatdesigncando.com/projects/produce-healthy-food-on-water-reduce-emissionsof-food-production-create-new-spaces-and-experiences-floating-food-farm/. [Accessed $12 \mathrm{Sept}$ 2020].

[5] J. Calderone, "This futuristic floating farm may take a bite out of global hunger - or totally sink," Business Insider, 13 Oct 2015. [Online]. Available: https://www.businessinsider.com/smart-floatingfarms-sustainable-forward-thinking-architecture-global-hunger-2015-9. [Accessed 12 Sep 2020].

[6] SMF, "Smart Floating Farm," Smart Floating Farms (SFF), [Online]. Available: https://smartfloatingfarms.com/Information. [Accessed 12 Sep 2020].

[7] TEMASEK, "what singapore's '30 by 30' food security goal means for businesses," AlphaBeta Strategy \& Economics, Singapore, 2020.

[8] UN, Convention on the Law of Sea., United Nations , 1982.

[9] UN, "Oceans and Law of the Sea," [Online]. Available: www.un.org/depts/los/convention_agreements/convention_overview_convention.htm. [Accessed 1008 2020].

[10] MARINEREGIONS, "Marine Gazetteer Placedetails," [Online]. Available: https://www.marineregions.org/gazetteer.php?p=details\&id=8485. [Accessed 03 Sept 2020].

[11] Ministry of Economy Japan, "Law bill for promoting the use of marine areas related to the development of marine renewable energy power generation facilities.," Ministry of Economy, Trade and Industry, , Japan, 2018.

[12] H. S. Lim, J. Jiang and Y. Tan, "The Singapore Aquaculture Industry - Contributing to Singapore's Food Security.".Word Aquaculture Society Magazine..

[13] DNV GL, "Rules for classification: Offshore units (RU-OU) - Offshore fish farming units and installations.," DNV GL, 2020.

[14] ABS, "Guide for building and classing -aquaculture installations.," ABS, 2020-06..

[15] UN FAO, "National Aquaculture Legislation Overview (NALO).," 2020. [Online]. Available: http://www.fao.org/fishery/nalo/search/en. [Accessed 10 Sep 2020]. 
[16] Singapore Government, "Singapore Statutes Online," [Online]. Available: https://sso.agc.gov.sg/Index. [Accessed 10 Aug 2020].

[17] MPA Singapore, "Prevention of Pollution of the Sea Act," 1991. [Online]. Available: https://www.mpa.gov.sg/web/portal/home/port-of-singapore/. [Accessed 2020].

[18] MPA, "Maritime and Port Authority of Singapore,," [Online]. Available: https://www.mpa.gov.sg/web/portal/home/port-of-singapore/operations/marineprojects/foreshore-and-marine-development-projects. [Accessed 10 Aug 2020].

[19] H. Cannaby, . M. D. Palmer, T. Howard and at all, "Projected sea level rise and changes in extreme storm surge and wave events during the 21st century in the region of Singapore," National Oceanography Centre, UK, 2016. [Online]. Available: http://nora.nerc.ac.uk/id/eprint/512443/1/os12-613-2016.pdf.

[20] "Climate of Singapore," Meteorogical Service of Singapore, [Online]. Available: http://www.weather.gov.sg/climate-climate-ofsingapore/\#: : :text=Northeast\%20Monsoon\%20Season(December\%2Dearly,from\%20December\%20t ०\%20early\%20January.. [Accessed 20 July 2020].

[21] B. D. Zoelaeha, "Fine sediment transport near coral reefs islands in the Singapore Strait, Phd thesis,," Delft University of Technology, June 2010.

[22] P. Tkalich, P. Vethamony, . Q.-H. Luu and M. T. Bab, "Sea level trend and variability in the Singapore Strait," Ocean Science, 8 March 2013. [Online]. Available:

https://os.copernicus.org/articles/9/293/2013/os-9-293-2013.pdf. [Accessed 10 Oct 2020].

[23] T. W. Rostena, K. Henriksena, . E. S. Hognesa and S. Summerfeltb, "Comparative economic performance and carbon footprint of two farming models for producing Atlantic salmon (Salmo salar): Land-based closed containment system in freshwater and open net pen in seawater.," NorwThe Conservation Fund, Freshwater Institute, USA, 2016.

[24] Aquacare Environment Inc., "Facebook," [Online]. Available: https://www.facebook.com/AquacareEnvironmentInc/photos/p.2053946974654481/205394697465 4481/?type=1\&theater. [Accessed 15 Sept 2020].

[25] N. Vargas, C. Gutierrez and S. Restrepo, "Oyster Mushroom Cultivation as an Economic and Nutritive Alternative for Rural Low-Income Women in Villapinzón (Colombia)," in Women in Industrial and Systems Engineering, Springer, Cham., 2019, pp. 561-587.

[26] Y. CELIK and . K. PEKER, "benefit/cost analysis of mushroom production for diversification of income in developing countries," Bulgarian Journal of Agricultural Science, vol. 3, no. 15, pp. 228-237, 2009.

[27] East Gwillimbury, "holbourne-mushroom-farm-2516-June-26-2018," East Gwillimbury, [Online]. Available: http://experienceeg.ca/holburne-mushroom-farm/holbourne-mushroom-farm-2516-june26-2018/. [Accessed 12 Sept 2020]. 
[28] FirePrice, "Products' prices," [Online]. Available: https://www.fairprice.com.sg/category/mushrooms. [Accessed 05 Sept 2020].

[29] D.A.Sumner, H.Gow, D.Hayes, W.Matthews, B.Norwood, J.T.Rosen-Molina and W.Thurman, "Economic and market issues on the sustainability of egg production in the United States: Analysis of alternative production systems".

[30] Wikimedia Commons, "Poultry Farm in Namakkal, Tamil Nadu," [Online]. Available: https://commons.wikimedia.org/w/index.php?curid=88231552. [Accessed 12 Sept 2020].

[31] V. Vrakking, D. Schubert and C. Zeidler, "Vertical Farm 2.0: Designing an Economically Feasible Vertical Farm - A combined European Endeavor for Sustainable Urban Agriculture," Jan 2017. [Online]. Available:

https://www.researchgate.net/publication/321427717_Vertical_Farm_20_Designing_an_Economical ly_Feasible_Vertical_Farm_-_A_combined_European_Endeavor_for_Sustainable_Urban_Agriculture.

[32] Lazada, "Production Prices," Lazada, [Online]. Available: https://www.lazada.sg/. [Accessed 12 Sept 2020].

[33] E. Runkle, "Crops Suitable for Vertical Farming," Greenhouse Production News, [Online]. Available: https://gpnmag.com/article/crops-suitable-for-vertical-farming/. [Accessed 15 Sept 2020].

[34] Open Electricity Market, " Wholesale Electricity Price," [Online]. Available:

https://www.openelectricitymarket.sg/business/purchase-options/wholesale-electricity-price. [Accessed 20 Sept 2020].

[35] Ship\&Bunker, "Singapore Bunker Prices," [Online]. Available: https://shipandbunker.com/prices/apac/sea/sg-sin-singapore\#VLSFO. [Accessed 12 Sept 2020].

[36] "LNG AS A MARINE FUEL - the investment opportunity," 2020. [Online]. Available: https://seaIng.org/wp-content/uploads/2019/01/190123_SEALNG_InvestmentCase_DESIGN_FINAL.pdf.

[37] DNV-GL, "Current price development oil and gas," [Online]. Available: https://www.dnvgl.com/maritime/Ing/current-price-development-oil-and-gas.html. [Accessed 05 Sept 2020].

[38] I. Memon , S. Noonari , M. Asif, S. Shah , M. Peerzado and at all, "Economic Analysis of Poultry Egg Production in Quetta District," J Fisheries Livest Prod 3, 2015.

[39] PUB, "Water Price," [Online]. Available: https://www.pub.gov.sg/watersupply/waterprice. [Accessed 10 Sept 2020].

[40] Alfa Laval, "Fresh water for life -Alfa Laval desalination solutions," [Online]. Available: http://www.alfalaval.com.co/globalassets/documents/products/process-solutions/desalinationsolutions/mechanical-vapour-compression/fresh-water-for-life.pdf.. [Accessed 1207 2020].

[41] B. E. Løfsgaard and E. Andersen, "Safe, Sufficient and Good Potable Water Offshore-Guidline," Oslo, 2017. 
[42] Craig R. Bartels, "Reverse osmosis membranes play key role in wastewater reclamation," Water Wolrd magazine, 01 Dec 2006.

[43] Warehouse Rental Singapore, "Commercial \& Industrial space for rent," [Online]. Available: https://warehouserentalsingapore.com/rental-rates-guide/. [Accessed 15 Sept 2020].

[44] M. Troell, "Integrated marine and brackishwater aquaculture in tropical regions: Research, implementation and prospects," 2013.

[45] D. C. Little and P. Edwards, "Integrated Livestock Fish Farming Systems," Food \& Agriculture Org., [Online]. Available:

https://www.researchgate.net/publication/259999240_Integrated_Livestock_Fish_Farming_Systems

[46] J. P. Chastain, J. J. Camberato and P. Skewes, "Poultry Manure Production and Nutrient Content," NCOFP MANURE USA.

[47] Moses Mwangangi Wambua, "A cost-benefit analysis of the fish farming enterprise productivity program project in kenya.," University of Iceland, Iceland, 2015.

[48] R. . O. Omenka and . G. . N. Anyasor, "Vegetable-Based Feed Formulation On Poultry Meat Quality," African Journal of Food Agriculture Nutrition and Development, vol. 10, no. 1, 2010.

[49] D. Grimm and H. A. B. Wösten, "Mushroom cultivation in the circular economy," Springer Nature journal, Utrecht, 2018.

[50] S. G. Shannon, "Effect of Vibration Frequency and Amplitude on Developing Chicken Embryos," Aircrew Protection Division, Fort Rucker, Alabama, 1994.

[51] DNV GL, "Class Notation Noise and Vibration," [Online]. Available: https://www.dnvgl.com/services/class-notations-noise-and-vibration-4712. [Accessed 31 Aug 2020].

[52] DNV GL, "Controlling underwater noise," [Online]. Available: dnvgl.com/expert-story/maritimeimpact/Controlling-underwater-noise.html. [Accessed 31 Aug 2020].

[53] G. Corkery, S. Ward, C. Kenny and P. Hemmingway, "Incorporating smart sensing technologies into the poultry industry.," Journal of World's Poultry Research,, vol. 3(4), p. 106-128, 2013.

[54] R. Gates, . K. Casey, . E. Wheeler, . H. Xin and . A. Pescatore, "U.S. broiler ammonia emissions inventory model.," Atmos. Environ., pp. 42, 3342-3350., 2008.

[55] Z. Liu, . W. Powers, D. Karcher, . R. Angel and T. Applegate, "Effect of Amino Acid Formulation and Supplementation on Nutrient Mass Balance in Turkeys.," Poultry Science,, pp. 90, 1153-1161, 2011.

[56] H. Xin, R. Gates, . A. Green, . F. Mitloehner, J. P. Moore and C. Wathes, "Environmental impacts and sustainability of egg production systems.," Poultry Science, pp. 90, 263-277., 2011. 